Reasearh article

\title{
The Eocene-Oligocene transition in the C-isotope record of the carbonate successions in the Central Mediterranean
}

\author{
Irene Cornacchia ${ }^{\mathrm{a}, *}$, Marco Brandano $^{\mathrm{a}, \mathrm{b}}$, Isabella Raffic ${ }^{\mathrm{c}}$, Laura Tomassetti ${ }^{\mathrm{a}}$, Isabella Flores ${ }^{\mathrm{a}}$ \\ a Dipartimento di Scienze della Terra, La Sapienza Università di Roma, P. Aldo Moro 5, 00185 Roma, Italy \\ ${ }^{\mathrm{b}}$ Istituto di Geologia Ambientale e Geoingegneria (IGAG) CNR, Sez. Sapienza, c/o Dipartimento Scienze della Terra, P.Aldo Moro 5, I-00185 Roma, Italy \\ " Dipartimento di Ingegneria e Geologia, Università degli Studi “G. d'Annunzio" Chieti- Pescara, via dei Vestini 31, 66013 Chieti, Italy
}

\section{A R T I C L E I N F O}

\section{Keywords:}

C-cycle

Carbonate ramp

Cenozoic

Majella

Massignano

\begin{abstract}
A B S T R A C T
The Eocene-Oligocene transition marks a fundamental step in the evolution of the modern climate. This climate change and the consequent major oceanic reorganisation affected the global carbon cycle, whose dynamics across this crucial interval are far from being clearly understood. In this work, the upper Eocene to lower Oligocene $\delta^{13} \mathrm{C}_{\mathrm{Carb}}$ and $\delta^{13} \mathrm{C}_{\mathrm{TOC}}$ records of a shallow-water and a hemipelagic carbonate settings within the Central Mediterranean area have been studied and discussed. The shallow-water carbon isotope signal has been analysed in the northern portion of the Apula Platform, cropping out in the Majella Mountain, Central Apennines (Santo Spirito Formation). A coeval Umbria-Marche basinal succession has been investigated in the Massignano section (Conero area, Central Italy). The purposes of this work are: to discriminate between the global and the local (Mediterranean) signature of C-isotope record during the Oi-1 event, to correlate the regional C-isotope signal with the global record, and to evaluate the carbon cycle dynamics across the greenhouse-icehouse transition through the integration of complementary records (shallow-water vs pelagic settings, $\delta^{13} \mathrm{C}_{\mathrm{Carb}} \mathrm{vs} \delta^{13} \mathrm{C}_{\mathrm{TOC}}$ ). The upper Eocene carbon isotope record of the analysed successions matches with the global signal. The overall trend shows a decrease of the $\delta^{13} \mathrm{C}_{\text {Carb }}$ and a contemporary increase of the $\delta^{13} \mathrm{C}_{\mathrm{TOC}}$. The decoupling of the two curves is consistent with a reduced fractionation effect by primary producers that characterised the interval between the Middle Eocene Climatic Optimum and the onset of the Oi-1 event. However, regional factors superimposed the global signal. In fact, the upper Eocene basinal $\delta^{13} \mathrm{C}_{\mathrm{TOC}}$ record is marked by short-term negative spikes, which possibly represent times of higher productivity triggered by the westward subtropical Eocene Neotethys current entering from the Arabian-Eurasian gateway. On the contrary, the shallow-water record does not display these short-term productivity pulses. A change in the carbonate factory is only recorded at the EoceneOligocene transition, marked by a reduction of the larger benthic foraminifera and the spread of seagrass and corals. Moreover, in the shallow-water record of the Santo Spirito Formation, no major carbon isotope shift related to the Oi-1 event is recorded due to the presence of extensive slumps that disrupt the bedding. These slumps are the main evidence of the sea-level drop that occurred concomitantly with the onset of the Antarctica ice-sheet, which caused the deepening of the storm wave base and increased the instability over the entire ramp.
\end{abstract}

\section{Introduction}

The Eocene-Oligocene transition (EOT) represents the most important step in the evolution of the modern icehouse climate. It marks the transition from the warm 'greenhouse world' when the atmospheric $\mathrm{pCO}_{2}$ was higher than 1000 ppm (Beerling and Royer, 2011; Pagani et al., 2014) and only transient ice-sheets could develop at low latitudes (Carter et al., 2017), to the modern 'icehouse' climate that is characterised by stable polar ice caps and lower $\mathrm{CO}_{2}$ concentrations (Pearson et al., 2009; Beerling and Royer, 2011). The EOT (Houben et al., 2012) culminates with a $\delta^{18} \mathrm{O}$ peak recorded in the lower Oligocene (33.55 Ma) deep-sea successions (Miller et al., 1991). This positive oxygen isotope shift, named Oi-1 event (Miller et al., 1991; Zachos et al., 1996, 2001; Coxall and Pearson, 2007; Lear et al., 2008), marks the development of a permanent ice sheet in Antarctica as much as $50 \%$ in volume of the present one (DeConto and Pollard, 2003; Liu et al., 2009; Miller et al., 2009; Bohaty et al., 2012). Several studies testify for a very dynamic and unstable polar ice cap in Antarctica from the early Oligocene to the late Miocene (Pekar and Deconto, 2006; Cook et al., 2013; Liebrand et al., 2017; Sangiorgi et al., 2018). Pekar and

\footnotetext{
* Corresponding author.

E-mail address: irene.cornacchia@uniroma1.it (I. Cornacchia).
} 
Deconto (2006) report different records showing that the ice-volume fluctuated between $50 \%$ and $125 \%$ of the present Eastern Antarctic ice sheet, while Liebrand et al. (2017) state a minimum waxing and waning of $85 \%$ to $110 \%$ of the present-day volume. However, it is overall accepted that an ice sheet persisted in Antarctica since the Oi-1 event.

Both the causes and the effects of the glaciation in Antarctica are still under debate. Overall, the main theories approaching this problem rely on two different hypotheses e.g. the isolation of Antarctica due to plate reorganisation, or the decrease of the atmospheric $\mathrm{CO}_{2}$ during late Eocene. The opening of the Tasmanian and Drake Passages during late Eocene was assumed as the main triggering cause of the glaciation since it led to the development of the Antarctic Circumpolar Current and therefore the thermal isolation of Antarctica (Kennet et al., 1975; Kennet, 1977). However, more recently, the decrease of $\mathrm{pCO}_{2}$ is considered the main controlling factor on the ice-growth in Antarctica (DeConto and Pollard, 2003; Pagani et al., 2011; Egan et al., 2013; Goldner et al., 2014; Galeotti et al., 2016). Regardless of the debate on the triggering causes, both the opening of the Drake Passage (Scher and Martin, 2004) and the onset of an Antarctic ice sheet (Goldner et al., 2014; Wright et al., 2018) altered the ocean circulation resulting in a general global ocean reorganisation that affected the carbon cycle, as marked by a positive $\delta^{13} \mathrm{C}$ isotope excursion recorded in the deep-sea successions (Zachos et al., 1996, 2001; Cramer et al., 2009) associated with a major deepening of the Calcite Compensation Depth (CCD) (Coxall et al., 2005). Different hypotheses have been suggested to explain this positive carbon isotope excursion, most of which are related to changes in the oceanic trophic regime and the associated primary productivity induced by sea level changes or changes in the global oceanography (Salamy and Zachos, 1999; Zachos and Kump, 2005; Coxall et al., 2005; Coxall and Pearson, 2007; Miller et al., 2009; Coxall and Wilson, 2011; Plancq et al., 2014).

The carbon cycle perturbation related to the Oi-1 event has been clearly identified in the deep-sea record of all the oceans at different latitudes (Zachos et al., 1996, 2001; Cramer et al., 2009), whereas little is known about the response of the shallow-water carbonate systems' to this carbon cycle perturbation (Jaramillo-Vogel et al., 2013, 2016). Notwithstanding that, even if often discontinuous, shallow-water carbonates are significantly more sensitive to temperature and trophic changes than deep-se-a successions. In fact, during the transition from the warm Eocene to the Oligocene 'icehouse', these major changes in climate, ice volume, and ocean circulation deeply influenced the composition and production of the carbonate factory (Nebelsick et al., 2005; Brandano et al., 2009, 2017a; Pomar et al., 2017).

The larger benthic foraminifera, which dominated the Eocene carbonate platforms (Racey, 2001, and references therein; Bassi, 2005; Beavington-Penney et al., 2005), experienced a major decline. In turn, zooxanthellate corals and coralline algae spread as main biota-producing sediment, and seagrass environments expanded strongly in the euphotic zone, influencing the facies association of the Cenozoic carbonate platforms (Nebelsick et al., 2005; Pomar and Kendall, 2008; Brandano et al., 2017a).

In this work, the carbon isotope record is studied in the EOT interval in two different contexts from the Central Mediterranean area. The first case study refers to sedimentary succession from the Apula Carbonate Platform (Central Apennines, Central Italy), in which the main lithofacies of the Santo Spirito Formation and $\delta^{13} \mathrm{C}$ of the whole-rock signal are analysed and discussed. This shallow-water carbon isotope signal is correlated with the $\delta^{13} \mathrm{C}$ record obtained in the Massignano section (Scaglia Variegata and Scaglia Cinera Fm, Conero area, Central Italy), which is the well-known Global Stratotype Section and Point (GSSP) of the Eocene-Oligocene boundary (Premoli Silva and Jenkins, 1993), and represents the Umbria-Marche basinal succession.

Through a precise correlation of the C-isotope records of the Mediterranean area with the global signal, we aim (i) at assessing the impact of C-cycle perturbations on shallow- and deep-water successions, and (ii) at evaluating the relationships between carbon cycle and shallow carbonates across this major greenhouse-icehouse transition.

\section{Geological setting}

The Apennine fold-and-thrust belt is the result of the collision of the Adria plate with the southern margin of Europe (Alvarez et al., 1974; Bally et al., 1986; Dewey et al., 1989; Doglioni, 1991; Rosenbaum et al., 2002a; Devoti et al., 2008; Carminati et al., 2012). The Apennine subduction started in the late Eocene (Lustrino et al., 2009), and it continued through Neogene until today (Boccaletti et al., 1990; Rosenbaum et al., 2002b; Doglioni et al., 1998; Carminati et al., 2010, 2012). The westward-dipping Apennine slab led to an eastward migration of the deformation fronts and related foredeeps, and subsequent extensional tectonics in the back-arc area where several basins opened during the Oligocene-Miocene interval on thin continental (the València Through) and oceanic (Alborán, Provençal and Thyrrenian Basin) crust (Carminati et al., 2012 and references therein). The Central Apennine consists of Triassic to Miocene deposits that can be ascribed to three different paleogeographic domains: the Apennine carbonate platforms (Latium-Abruzzi and Apula platforms), the Umbria-Marche basin, and the Molisano basin (Colacicchi, 1967; Crescenti et al., 1969; Parotto and Praturlon, 1975; Bernoulli, 2001; Vezzani et al., 2010). In this study, the northern extension of the Apula platform, represented by the Majella Mountain and the Marche basinal successions, are investigated (Fig. 1a).

\subsection{The Majella Mountain}

The Majella Mountain (Fig. 1b) is a $35 \mathrm{~km}$-long anticline that is convex towards the northeast, and plunges both northward and southward (Patacca et al., 2008). Its outcropping succession consists of Upper Jurassic to upper Miocene limestones and dolostones (Crescenti et al., 1969). During the Mesozoic, a steep erosional escarpment separated the platform top from the basin, which extended northward (Fig. 1c). By the late Campanian, the platform prograded over the basin, that was filled up by onlapping sediments (Vecsei et al., 1998). Thus, the Paleogene evolution of the Majella carbonate platform, corresponding to the Santo Spirito Formation, is represented by a continuous sedimentation along the platform margin and the slope, while the platform top shows long-term hiatuses and discontinuous deposits. In the upper Rupelian a discontinuity surface occurs, separating the Santo Spirito Formation from the Bolognano Formation (upper Rupelianlower Messinian), which represents a carbonate ramp developed above the former shallow deposits of the platform (Mutti et al., 1997; Brandano et al., 2012, 2016a). The evolution of the Oligocene-Miocene ramp ended in the Messinian with the deposition of the Turborotalita multiloba Marls (Carnevale et al., 2011), followed by the Gessoso-Solfifera Formation (Crescenti et al., 1969). Lastly, during the early Pliocene, the Majella Mountain was involved into the foredeep system of the Apennine orogeny (Cosentino et al., 2010).

\subsection{The Umbria-Marche Domain}

The Umbria-Marche Domain consists of an Upper Triassic-Miocene sedimentary succession deposited in the northern margin of the Tethys (Fig. 1a and d). During the Late Triassic, the rifting of the Tethys led to a marine transgression, testified by the evaporitic deposition of the Anidridi di Burano and, subsequently, by the development of the Calcare Massiccio carbonate platform (Pialli, 1971). During the Early Jurassic, the Calcare Massiccio platform drowned due to the rift-related extensional tectonics, and the Umbria-Marche domain evolved into a wide basin characterised by intrabasinal structural highs (Centamore et al., 1971; Bernoulli and Jenkyns, 1974; Brandano et al., 2016b) until the Late Jurassic.

This heterogeneous paleogeography ended with the deposition of pelagic mudstones (the Maiolica Formation, Titonian to Albian in age) 

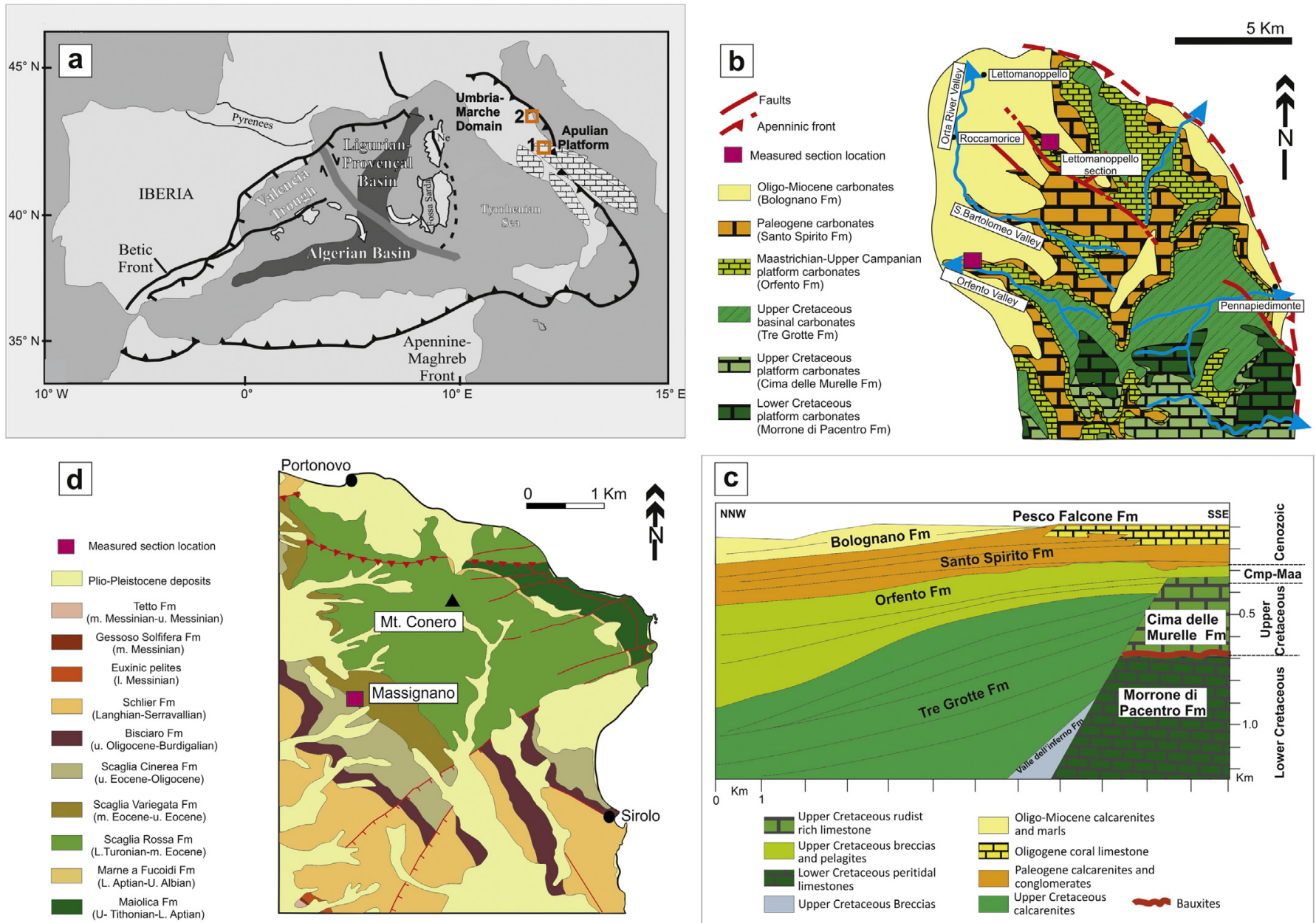

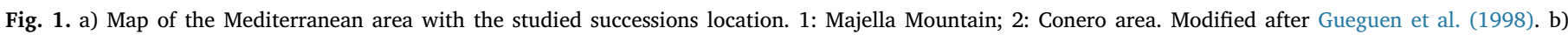

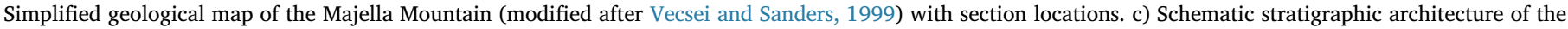

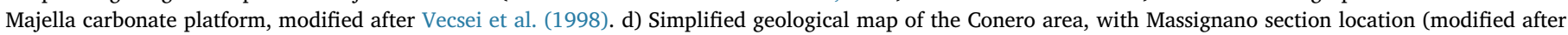
Coccioni et al., 1997).

that levelled the inherited topography (Alvarez, 1990). The evolution of the Umbria-Marche basin during the Cretaceous to Miocene interval resulted in the transition from pelagic to hemipelagic sedimentation, characterised by a constant increase of siliciclastic content, in a context of significant subsidence (Marchegiani et al., 1999; Guerrera et al., 2012). The last phase of orogeny is represented by a W-to-E migration of siliciclastic turbidites (Marnoso Arenacea Fm.) occurring in middle to late Miocene (Alvarez, 1999; Guerrera et al., 2012).

\section{Materials and methods}

The studied materials originate from three different stratigraphic sections: the Lettomanoppello and the Orfento Valley sections (Majella Mountain, Central Italy), and the Massignano section (Conero area, Central Italy) (Fig. 2). Eighty-five thin sections of the Santo Spirito Formation, belonging to both the sections, were observed at the petrographic microscope for textural characterisation and skeletal components identification.

Previously published and newly generated data on calcareous nannofossil assemblages were considered for biostratigraphic characterisation. Eleven samples from the Orfento Valley section, collected from marly layers and chalk inclusions within cherty nodules if present, were examined. Smear-slides for nannofossils analysis were obtained following the procedure defined by Bown and Young (1998) and observed under a polarising microscope $(\times 1200$ magnification $)$. The nannofossil biostratigraphic data of the Lettomanoppello section are from Raffi et al. (2016). For biozones and biochronology we refer to the Paleogene Zonation of Agnini et al. (2014).

The Lettomanoppello and the Massignano sections were sampled for carbon isotope stratigraphy, and a $0.5 \mathrm{~m}$ sampling interval was chosen. Stable isotope analyses were carried out at the Isotope Geochemistry Laboratory of the Istituto di Geologia Ambientale e Geoingegneria (IGAG-CNR) of Rome, and carbon and oxygen stable isotope ratios were measured on 63 bulk samples of the Lettomanoppello section. The whole-rock analyses were performed with a Finnigan Delta Plus Mass spectrometer coupled with a gas chromatography-based Gas Bench II, and stable isotope ratios were calibrated with the international NBS19 carbonate standard. All the results are expressed in the Vienna Pee Dee Belemnite (VPDB) scale. The analytical error was $\pm 0.1 \%$ (SD) based on replicate standards.

$\delta^{13} \mathrm{C}_{\mathrm{TOC}}$ was measured on 46 samples belonging to the Massignano section. Rock samples were hand-crushed in an agate mortar. To remove the carbonate fraction, $0.5 \mathrm{~g}$ of powder per sample was treated with $40 \mathrm{ml}$ of an $\mathrm{HCl} 1 \mathrm{M}$ solution and shaken with a magnetic stirrer for $20 \mathrm{~min}$. After $20 \mathrm{~min}$, the $\mathrm{pH}$ of the solution was $\sim 2$, indicating that the entire carbonate fraction was consumed and that the reaction was complete. The residual powder was rinsed with deionised water and oven-dried at $50{ }^{\circ} \mathrm{C} . \delta^{13} \mathrm{C}_{\mathrm{TOC}}$ analyses were performed with a Finnigan Delta Plus Mass spectrometer coupled with a Flash-1112 Thermo Elemental Analyzer. Organic matter carbon isotope ratios were calibrated with the IAEA-CH- 6 and IAEA-CH-7 international standards. The analytical error was $\pm 0.3 \%$ based on replicate standards. 


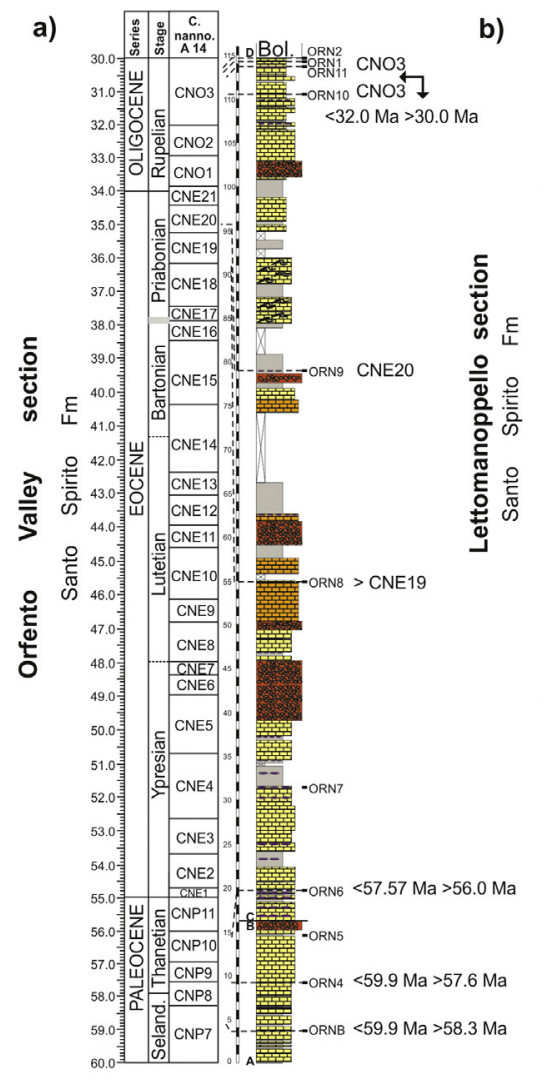

b) c)

Fig. 2. Stratigraphic sections with carbon isotope records plotted against stratigraphic depth. a) Orfento Valley stratigraphic section; b) Lettomanoppello section; c) Massignano section. Age constraints for the Santo Spirito Formation (Orfento Valley and Lettomanoppello sections) are provided by calcareous nannofossil biostratigraphy (this work; Raffi et al., 2016) and refer to the Paleogene Zonation of Agnini et al. (2014). Age constraints for the Massignano section are referred to in Coccioni et al. (1988) and Premoli Silva and Jenkins (1993). A 14 = calcareous nannofossil zonation of Agnini et al. (2014). B $95=$ planktonic foraminifera zonation of Berggren et al. (1995). Bu 73 = calcareous nannofossil zonation of Bukry (1973). M 71 = calcareous nannofossil biozones of Martini (1971).
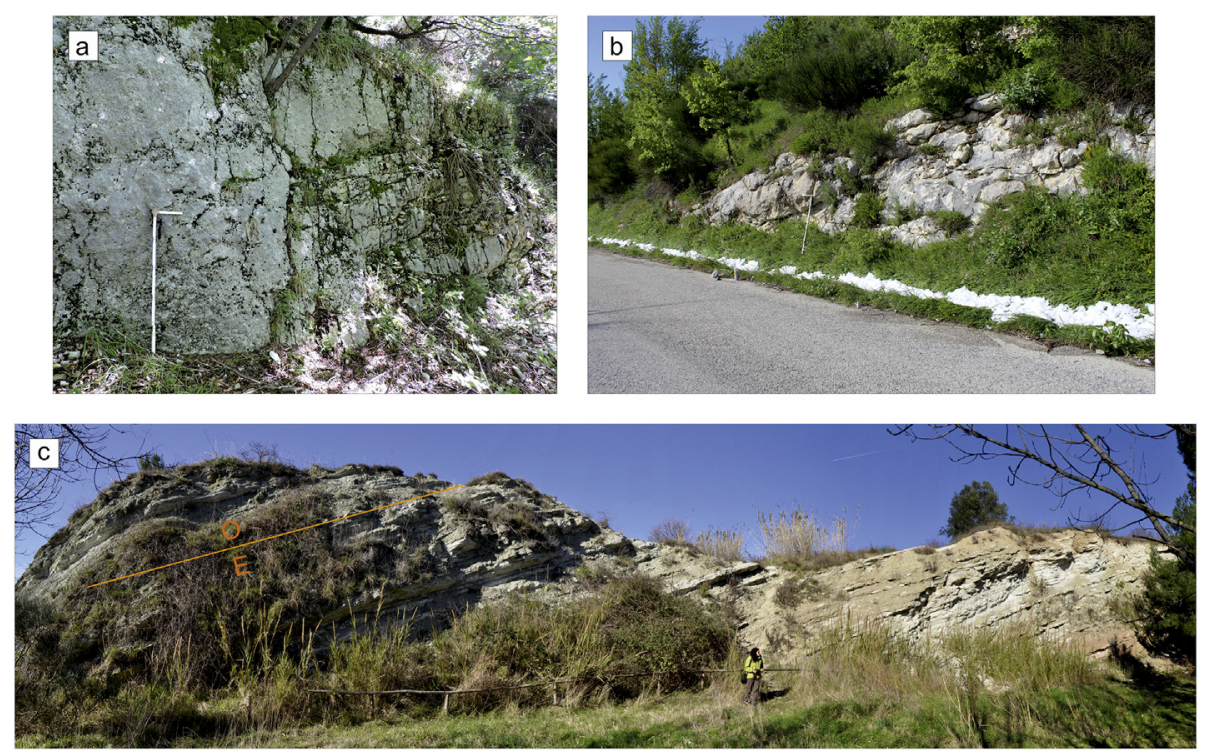

Fig. 3. a) Conglomerate interval interrupting the normal outer ramp sedimentation in the Orfento Valley section. b) Slumps within the lower Oligocene portion of the Lettomanoppello section. c) Massignano section, the Eocene-Oligocene boundary is marked with the orange line. 

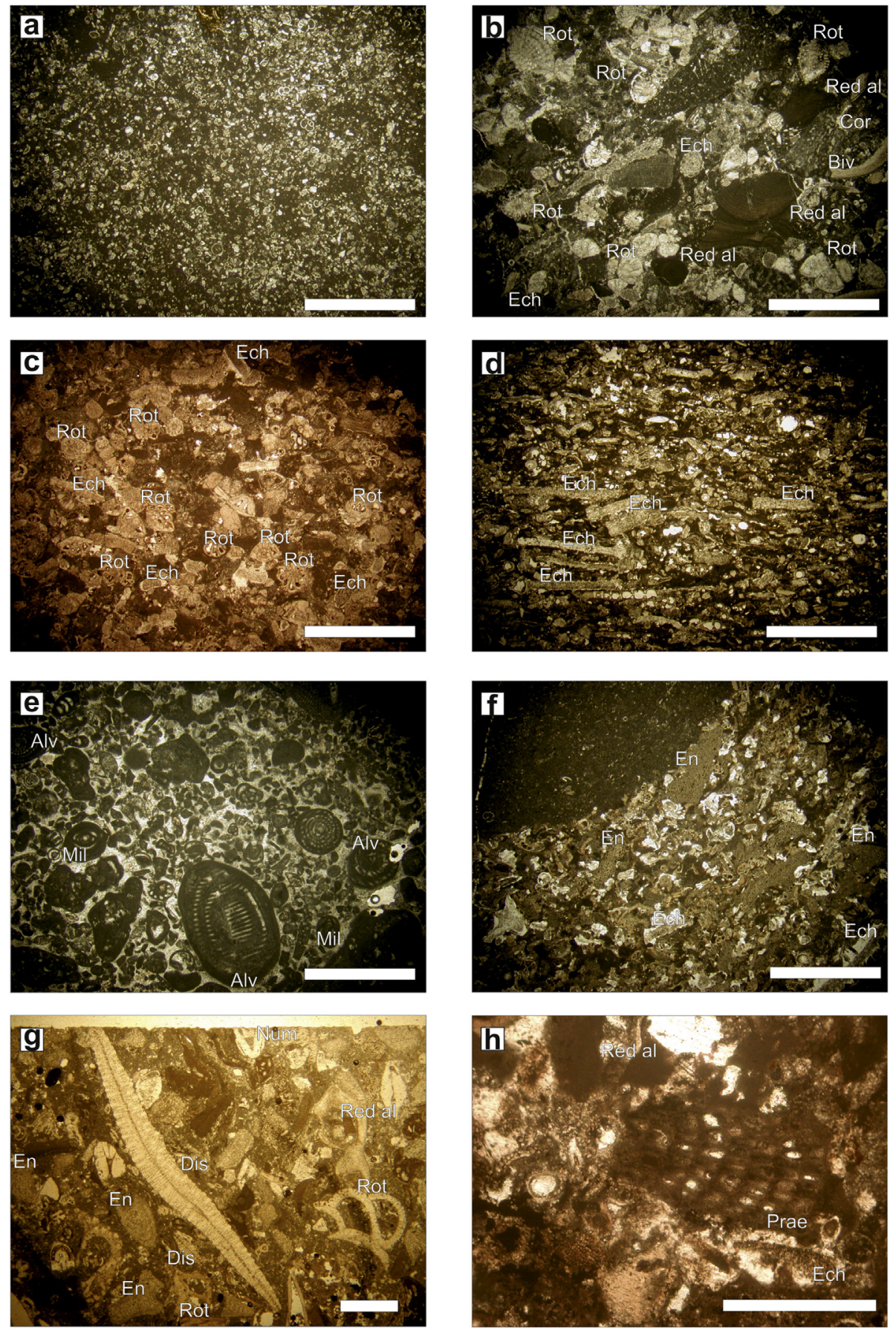

Fig. 4. Miocrofacies of the Santo Spirito Formation. a) Highly bioturbated packstone with planktonic foraminifera. b) Bioclastic packstone. C) Packstone with rotalids. d) Packstone with echinoid fragments. e) Grainstone with Alveolina and miliolids. f) Packstone with encrusting foraminifera and intraclasts. G) Floatstone with LBF. h) Floatstone with LBF. Alv: Alveolina. Biv: Bivalve fragments. Cor: coral fragments. Dis: Discocyclina. Ech: echinoid fragments. En: encrusting foraminifera. Mil: miliolids. Num: nummulitids. Prae: Praerhapydionina cf. 40elicate. Red al: red algae crusts and fragments. Rot: rotalids. Scale bar $=1 \mathrm{~mm}$.

\section{Results}

\subsubsection{The Orfento Valley section}

The Orfento Valley section (Figs. 2a and 3a) consists of the upper Paleocene-lower Oligocene portion of the Santo Spirito Formation. The composite section is $114.6 \mathrm{~m}$ thick, the first section (A-B), is $16.2 \mathrm{~m}$ thick, the second (C-D) is $98.4 \mathrm{~m}$ thick (Fig. 2a). The first $15.1 \mathrm{~m}$ of the Orfento A-B section are represented by wackestones to packstones rich in planktonic foraminifera (Fig. 4a) alternated with laminated bioclastic packstones. The main components of the bioclastic packstones are highly fragmented larger benthic foraminifera (LBF), such as Nummulites, Discocyclina, rotalids, and red algae crusts, together with echinoids and bivalve fragments (Fig. 4b, c, and d). Thin marly layers alternate with this calcareous facies of the Orfento A-B section, which is interrupted by a $1.1 \mathrm{~m}$-thick conglomerate characterised by an erosional basal surface with LBF and intraclasts. The base of the Orfento CD section consists of $22.2 \mathrm{~m}$ of coarse packstones with LBF alternated with mudstones/wackestones rich in planktonic foraminifera. Cherty nodules are very abundant in this interval.

At $\mathrm{m}$ 39.0, a $7 \mathrm{~m}$-thick conglomerate crops out. This conglomerate is 
chaotic and poorly sorted. LBF and coral fragments were identified together with intraclasts. The section continues with a $16.8 \mathrm{~m}$-thick interval dominated by bioclastic packstones with LBF, such as Nummulites and Alveolina, alternated with floastones with Alveolina in a grainstone matrix dominated by abundant miliolids and peneroplids, and with packstones containing encrusting foraminifera, such as Gypsina moussaviani, red algae crusts, and nodules (Fig. 4e and f). These facies are interrupted by two conglomerate intervals $0.6 \mathrm{~m}$ - (m 49.5) and $2.8 \mathrm{~m}$-thick (m 59). This portion of the Orfento C-D section ends with a $3.50 \mathrm{~m}$-thick interval of wackestones with planktonic foraminifera. Cherty nodules are common.

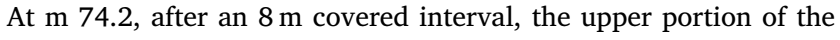
Orfento C-D section crops out. It consists of an alternation of bioclastic packstones with LBF and wackestones with planktonic foraminifera. A $1.0 \mathrm{~m}$-thick conglomerate interrupts the normal sedimentation at $77.5 \mathrm{~m}$. From $84.5 \mathrm{~m}$ to $92.0 \mathrm{~m}$, an interval of biocalstic packstones with LBF characterised by extensive slumps occurs. The uppermost conglomerate, which is $1.9 \mathrm{~m}$-thick, crops out at $101 \mathrm{~m}$. The $13.6 \mathrm{~m}$ interval at the top of the section consists of alternating very fine bioclastic packstones and planktonic-rich wackestones. Chert occurs in nodules and lists up to the top of the section (Fig. 2a).

4.1.1.1. Biostratigraphy and age constraints. Although the observed nannofossil assemblages in the sample from the Orfento Valley composite section are generally scarce and show moderate to poor preservation, it was possible to obtain some biostratigraphic and biochronologic constraints based on the presence of some marker species. In the few samples from the Orfento A-B section, and in a marly interlayer cropping out at $\mathrm{m} 3.4$ of the Orfento C-D section (Fig. 2a), the presence of specimens belonging to the genus Fasciculithus ( $F$. ulii group, F. pileatus, F. tympaniformis) indicate a biostratigraphic position included in the interval between Zones CNP7 and CNP9 of Agnini et al. (2014) (Plate 1-10). Therefore, the lower part of the composite Orfento section corresponds to the interval Selandian-lower Thanetian $(<59.9 \mathrm{Ma}$ and $>57.0 \mathrm{Ma}$ ). In the interval from $\mathrm{m} 20$ to $\mathrm{m}$ 55 in the composite section, the abundance of calcarenites and resedimented material limited the availability of samples suitable for biostratigraphy (Fig. 2a). The nannofossil assemblage observed in a marly interlayer at $55 \mathrm{~m}$, and in the chalk found in a cherty nodule at $79 \mathrm{~m}$, allows us to ascribe this interval to the Priabonian (CNE 19 and CNE20 of Agnini et al., 2014) due to the presence of very rare Discoaster saipanensis and D. barbadiensis and Ericsonia formosa (Plate 1 11-14). In the uppermost portion of the section (m 110.5 and $\mathrm{m}$ 113.5), the few samples show a scarce, but typical, lower Oligocene nannofossil assemblage, which places the top of the section in the CNO3 Zone (Agnini et al., 2014).

\subsubsection{The Lettomanoppello section}

The Lettomanoppello section represents the middle Eocene-lower Oligocene portion of the Santo Spirito Formation, and the section is $87 \mathrm{~m}$ thick. The first interval consists of $9 \mathrm{~m}$ of highly bioturbated wackestones/packstones rich in planktonic foraminifera. The foraminiferal assemblage is dominated by globigerinids, such as Globigerina, Globigerinatheka, and Turborotalia cerroazulensis, and minor components are sponge spicules, echinoid and mollusc fragments. The following interval is represented by a $2.4 \mathrm{~m}$ thick interval of LBF floatstones to rudstones. The main components are LBF, such as Nummulites, Assilina, Discocyclina, and rotalids (Figs. 2b and 4f). Other components are encrusting foraminifera, such as Gypsina and Acervulina, Textularia, Nodosaria, red algae, and echinoid and mollusc fragments (Fig. 4g).

From $\mathrm{m} 10.6$ to $\mathrm{m} 69$, the section consists of the alternation of bioclastic packstones and highly bioturbated wackestones rich in planktonic foraminifera (Fig. 2b). The main components of the bioclastic packstones are encrusting and epiphytic foraminifera, such as Gypsina moussaviani usually hooked, Planorbulina, Lobatula lobatula and nubecularids. Both articulated branches and non-articulated crusts of red algae, sometimes hook-shaped, among which Sporolithon and Subterraniphyllum, are frequent. Echinoid and mollusc, bryozoan, and Ditrupa fragments are common, together with small benthic foraminifera (SBF), such as miliolids, small rotalids, Lenticulina, textularids, and buliminacea, such as Bolivina. At $69 \mathrm{~m}$, a $4.50 \mathrm{~m}$-thick interval of floatstones/rudstones with LBF occurs. Among the LBF tests, Phraerhapydionina cf. delicata has been identified (Fig. 4h). This interval is characterised by extensive slumps. The last $13.6 \mathrm{~m}$ of the section consist of bioturbated wackestones rich in planktonic foraminifera, interrupted at $82.5 \mathrm{~m}$ by $3 \mathrm{~m}$ of bioclastic packstones. Cherty nodules occur at $75 \mathrm{~m}$. A discontinuity surface marks the passage to the overlying Bolognano Formation at $\mathrm{m} 87$.

4.1.2.1. Biostratigraphy and age constraints. Previously obtained nannofossil data from the Lettomanoppello section (Raffi et al., 2016) permitted us to obtain a detailed biostratigraphic classification of the section referring to Agnini et al. (2014) Zonation. The lower portion (up to $21.2 \mathrm{~m}$ ) corresponds to the mid-Eocene (Bartonian) Zone CNE15 based on the presence of Cribrocentrum reticulatum, Sphenolithus obtusus, Sphenolithus spiniger, and Dictyococcites bisectus (Plate 1 20-23). Above, in a sample from a marly layer at $37.8 \mathrm{~m}$, the observed nannofossil assemblage indicates Zone CNE19 (Discoaster saipanensis TZ), thus ascribing the central portion of the section to the upper Eocene (Priabonian) (Plate 1 15-19). The biostratigraphic results from the upper portion of the section indicate the transition to the lower Oligocene. In fact, a marly layer at $\mathrm{m} 64.50$ contains a nannofossil assemblage belonging to Zone CNO1 (Ericsonia formosa CRZ, age between 34 and $33 \mathrm{Ma}$ ), followed above (just below the boundary with the Bolognano Formation) by sediments of Zone $\mathrm{CNO} 3$ (Dictyococcites bisectus PRZ, age $<32 \mathrm{Ma}$ ) with $D$. bisectus, Sphenolithus predistentus, and Sphenolithus celsus (Plate 1 24-25).

4.1.2.2. The $C$ isotope record. The upper Eocene-lower Oligocene $\delta^{13} \mathrm{C}_{\text {Carb }}$ values of the Lettomanoppello section range between $+0.7 \%$ and $+1.9 \%$ (Fig. $2 \mathrm{~b}$ ). The lower portion of the carbon isotope curve, from $\mathrm{m} 37.8$ to $\mathrm{m} 50.8$ in the section, shows a stationary trend with the values fluctuating between $+1.4 \%$ and $+1.9 \%$. A sharp negative shift of $0.7 \%$ amplitude is recorded starting from $50.8 \mathrm{~m}$ with values falling first to $+1.1 \%$ at $51.8 \mathrm{~m}$, and then falling further to $+0.7 \%$ at $62.8 \mathrm{~m}$ in correspondence to the base of the Oligocene. This overall negative shift of $1.1 \%$ amplitude is the most significant in the analysed record. A $0.8 \%$ amplitude positive shift is recorded above (from 62.8 to $64.3 \mathrm{~m}$ ), with values rising to $+1.5 \%$. Whereas, the upper portion of the curve shows a stationary trend, with the $\delta^{13} \mathrm{C}_{\text {Carb }}$ values fluctuating around $+1.0 \%$ up to the end of the measured interval in the section (at $69.8 \mathrm{~m}$ ).

\subsubsection{The Massignano section}

The Massignano section represents the upper Eocene-lower Oligocene interval of the Umbria-Marche basinal succession. It is $23.0 \mathrm{~m}$ thick, and comprises the Scaglia Variegata and Scaglia Cinerea Formations (Figs. 2c and 3c). The Scaglia Variegata Formation consists of alternating reddish and greenish marls, calcareous marls, and marly limestones. This interval is characterised by horizontal and homogeneous beds, ranging in thickness between few and $50 \mathrm{~cm}$ centimetres. Bioturbation is common. The Scaglia Cinerea consists of homogeneous hemipelagic grey marls and marly limestones. Beds are tabular and range between few and $80 \mathrm{~cm}$. Bioturbation is present in all the lithologies. Ten biotite-rich layers related to volcanic events characterise the section: six in the Scaglia Variegata, and four in the Scaglia Cinerea (Jovane et al., 2009). Lastly, three iridium-rich layers, cropping out at $5.61 \mathrm{~m}, 6.17 \mathrm{~m}$, and $10.28 \mathrm{~m}$, are interpreted as being linked to impactoclastic events (Bodiselitsch et al., 2004) (Fig. 2c). The boundary between the Scaglia Variegata and the Scaglia Cinerea falls at $12.0 \mathrm{~m}$ (Coccioni et al., 1988). 


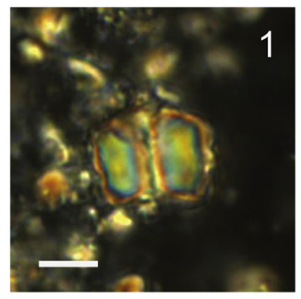

Fasciculithus cf. ulii

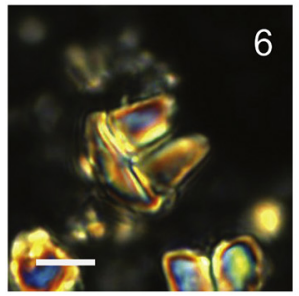

Fasciculithus pileatus

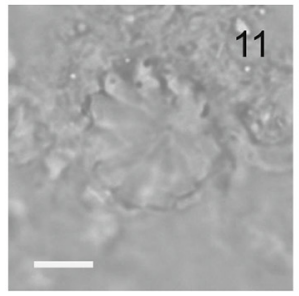

Discoaster mohleri

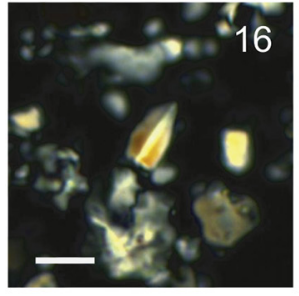

Sphenolithus intercalaris

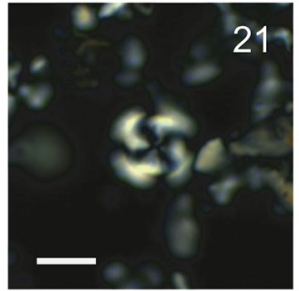

Cribrocentrum reticulatum

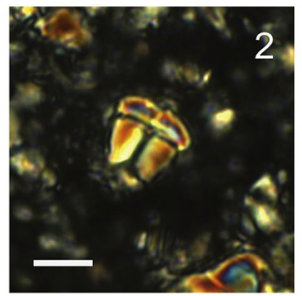

Fasciculithus pileatus

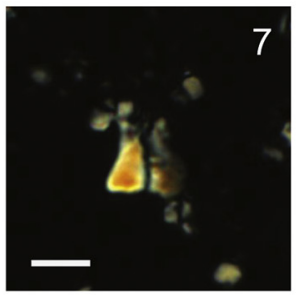

Fasciculithus cf. alanii

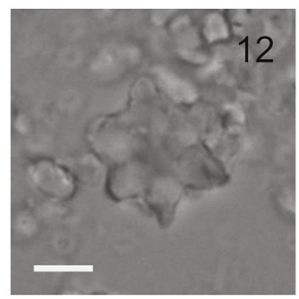

Discoaster saipanensis

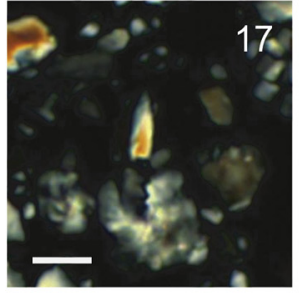

Sphenolithus intercalaris

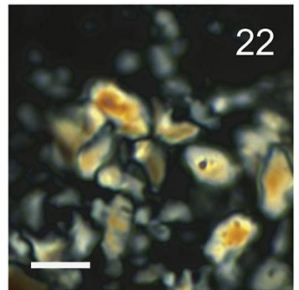

Sphenolithus radians

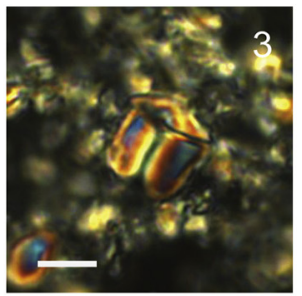

Fasciculithus pileatus

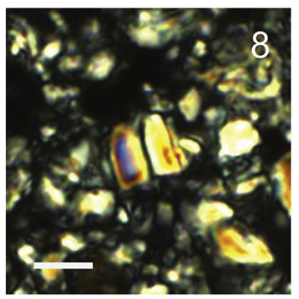

Fasciculithus tympaniformis

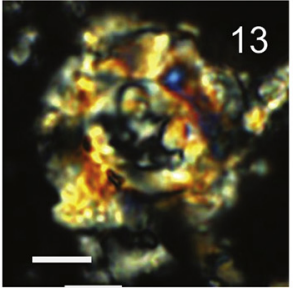

Reticulofenestra umbilicus

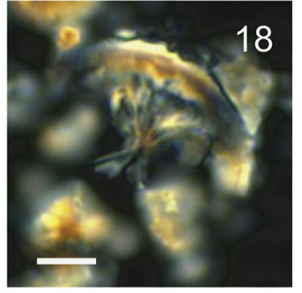

Chiasmolithus oamaruensis

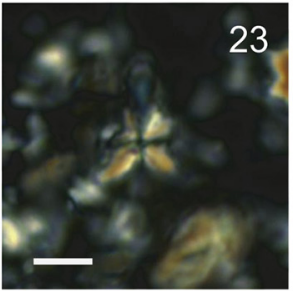

Sphenolithus radians

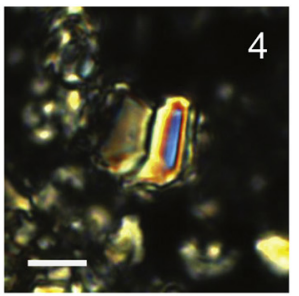

Fasciculithus ulii

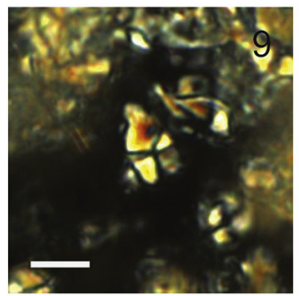

Sphenolithus anarrhopus

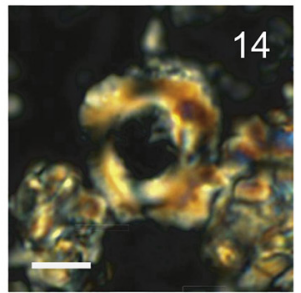

Reticulofenestra umbilicus

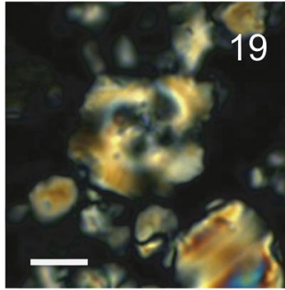

Ericsonia formosa

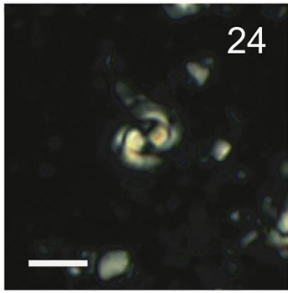

Clausicoccus subdistichus

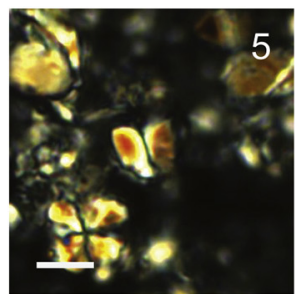

Fasciculithus tympaniformis

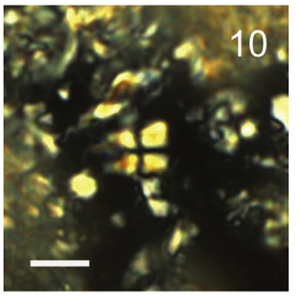

Sphenolithus anarrhopus

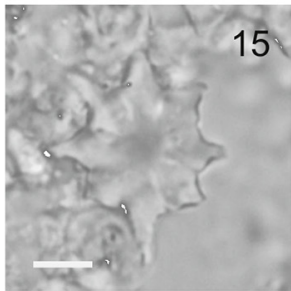

Discoaster saipanensis

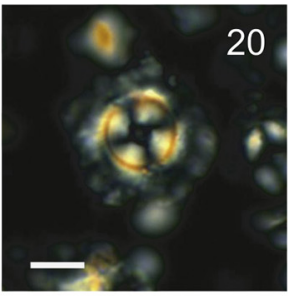

Ericsonia formosa

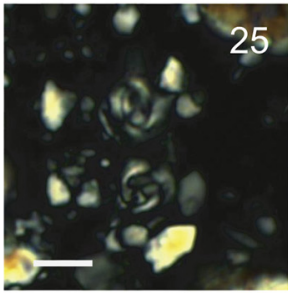

Clausicoccus subdistichus

Plate 1. Microphotographs of selected calcareous nannofossils in samples from the Orfento (ORN) and Lettomanoppello (LEN) sections. Scale bar $5 \mu$ m.

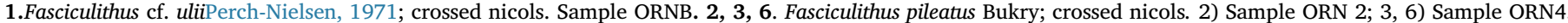

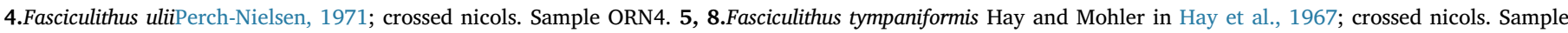

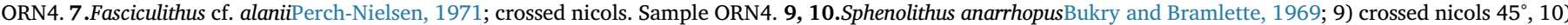

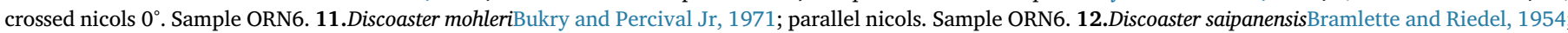

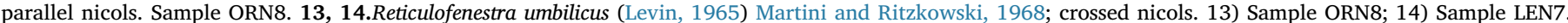

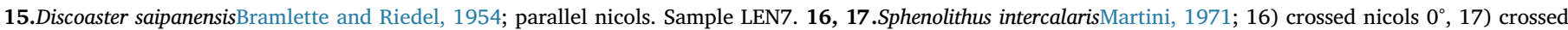

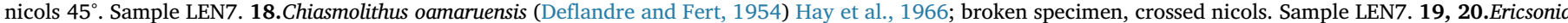

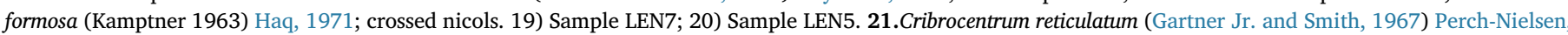

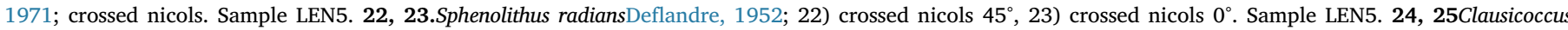
subdistichus Roth and Hay in Hay et al., 1967 Prins; crossed nicols. Sample LEN8.

4.1.3.1. Biostratigraphy and age constraints. Based on planktonic foraminifera biostratigraphy, the Massignano section spans from Priabonian to Rupelian (Coccioni et al., 1988; Premoli Silva and Jenkins, 1993). The base of the section is placed in the upper P15 Zone of Blow (1969) and Berggren et al. (1995), or the top of the nannofossil biozone CNE17 of Agnini et al. (2014). The top of the section falls into the P18 Zone (Blow, 1969; Berggren et al., 1995), which corresponds to the CNO1 Zone of Agnini et al. (2014). The Eocene/Oligocene boundary, marked by the extinction of the Hantkeninidae, is placed at $19 \mathrm{~m}$ (Coccioni et al., 1988). The calcareous nannofossils commonly used as markers for the late Eocene-early Oligocene are Discoaster saipanensis (last occurrence at 34.44 Ma; Pälike et al., 2006) and Clausicoccus subdistichus, whose increase (equivalent to 'Acme Ericsonia obruta') approximates the 
Eocene/Oligocene boundary at 33.88 Ma (Pälike et al., 2006). Both biohorizons are recognised in the Massignano section (Premoli Silva and Jenkins, 1993).

4.1.3.2. The $C$ isotope record. The upper Eocene-lower Oligocene $\delta^{13} \mathrm{C}_{\mathrm{TOC}}$ record at Massignano ranges between $-28.2 \%$ and $-25.2 \%$ (Fig. 2c). An overall increasing trend is evident throughout the entire carbon isotope curve. The lowest portion of the curve (from 0 to $8.5 \mathrm{~m}$ ) shows a stationary trend, with the values fluctuating around $-27.5 \%$. A $1.5 \%$ abrupt negative shift occurs between 8.5 and $10.5 \mathrm{~m}$, with the values decreasing from $-26.7 \%$ down to $-28.2 \%$, that represents the lowest value recorded in the section. The distinct positive trend ( $>2 \%$ in amplitude) recorded from 10.5 to $19.0 \mathrm{~m}$, with the values rising to $-26.0 \%$, corresponds to the Eocene-Oligocene boundary interval. The carbon isotope record in the lowermost Oligocene shows the values fluctuating between $-26.7 \%$ o and $-26.0 \%$ from 19.0 to $21.5 \mathrm{~m}$, and rising to $-25.2 \%$ at the top of the section.

\section{Discussion}

\subsection{Facies association and depositional model of the Santo Spirito formation}

The Santo Spirito Formation represents a carbonate platform developed in the Majella Mountain during the Paleogene, and it can be referred to as the standard model for Cenozoic carbonate ramps of Buxton and Pedley (1989). The recognised lithofacies can be ascribed to an outer ramp and to the adjacent basin environments. In particular, the facies with highly bioturbated wackestones to packstones and planktonic foraminifera is interpreted as deposited within the aphotic zone and below the storm wave base of the outer ramp where only photo-independent organisms accumulate. The facies typical of an outer ramp environment gradually pass into facies corresponding to basinal settings, where marly wackestones to mudstones with planktonic foraminifera occur. In this lower portion of the ramp, accumulation of abundant bioclastic turbidites and debris flow deposits occurs, which constitute a complex fan system and interrupt the normal outer ramp (cf. Payros et al., 2007).

Analysis of the skeletal components of the bioclastic packstones, the floatstones/rudstones lithofacies, and the clasts of the conglomerates, permits the inference of different facies' belts that constitute the inner portions of the platform. The major components identified in the bioclastic packstones, such as encrusting foraminifera and hooked-shaped red algae crusts, together with miliolids and alveolinids, indicate the presence of a vegetated environment developed within the euphotic zone as in the inner ramp (Beavington-Penney et al., 2004; Tomassetti et al., 2016).

The seagrass meadows hosted an important carbonate factory of the Cenozoic inner ramps, where encrusting, epiphytic, and miliolids foraminifera lived together with red algae and molluscs (Buxton and Pedley, 1989; Beavington-Penney et al., 2004; Brandano et al., 2016c; Tomassetti et al., 2016; Tomás et al., 2016). The middle ramp was dominated by nummulitids in the upper portion, and distally by orthofragminids, as evident by the occurrence of common Discocyclina tests in the LBF-rich floatstones/rudstones. During the late Eocene, zooxanthellate corals and red algae also occurred, as testified by the presence of these components in the conglomerates and in the LBF floatstones to rudstones lithofacies observed in the Orfento Valley section.

\subsection{Diagenetic overprint over $\delta^{13} C_{\text {Carb }}$ and $\delta^{13} C_{T O C}$ records}

Precipitation of carbonates is associated with only little carbon isotopic fractionation relative to the dissolved inorganic carbon (DIC). Therefore, the $\delta^{13} \mathrm{C}$ of both inorganic and biologically precipitated carbonate must be very close to the value of dissolved inorganic carbon in the ocean (Saltzman and Thomas, 2012), thus making the $\delta^{13} \mathrm{C}_{\text {carb }}$ a very good proxy of the isotopic composition of the DIC at the moment of the carbonate precipitation. Furthermore, both $\delta^{13} \mathrm{C}_{\mathrm{Carb}}$ and $\delta^{13} \mathrm{C}_{\mathrm{TOC}}$ are almost insensitive to temperature changes (Grossman and Ku, 1986; Hayes et al., 1999; Maslin and Swann, 2005; Galimov, 2006; Burla et al., 2008). Pelagic carbonates are considered the most reliable record to study carbon isotope stratigraphy as they are not affected by meteoric diagenesis, and they are more continuous and better age-constrained (Weissert et al., 2008and references therein).

Several recently published papers have demonstrated that shallowwater carbonates can preserve the original carbon isotope signature (John et al., 2003; Mutti et al., 2005; Franceschi et al., 2014; Brandano et al., 2015; Frijia et al., 2015), and show higher amplitude carbon isotope shifts in comparison to the coeval pelagic successions (Brandano et al., 2017b). Within the shallow-water skeletal associations, the heterozoan carbonates have greater potential to preserve the original marine isotopic ratios compared to the photozoan skeletal assemblages (Mutti et al., 2006) due to their mineralogical composition that is low-Mg calcite-dominated, which makes them more resistant to diagenetic alteration.

The microfacies analyses of the samples used for carbon isotope measurements show that the skeletal assemblages are dominated by low-Mg calcite shells, coupled with occasionally common H-Mg calcite organisms such as echinoids or red algae, whereas no aragonitic organisms are present. Only a minor growth of calcite cements is present, testifying for a diagenesis in a normal marine environment (Flügel, 2004). There isn't any evidence of deep burial diagenesis, neither of subaerial exposure, nor of diagenesis in a meteoric environment. Furthermore, the global compilation of $\delta^{13} \mathrm{C}_{\text {Carb }}$ values from benthic foraminifera records for the late Eocene-early Oligocene shows a range varying between $0 \%$ and $+2 \%$ (Cramer et al., 2009). Therefore, the Santo Spirito Formation carbon isotope record falls precisely within the coeval carbonate $\delta^{13} \mathrm{C}_{\text {Carb }}$ range allowing us to rule out any major diagenetic overprint that could have affected the investigated succession (Fig. 2b). Likewise, the $\delta^{13} \mathrm{C}_{\mathrm{TOC}}$ record of the Massignano section is consistent with the $\delta^{13} \mathrm{C}$ of marine phytoplankton, with a significantly minor portion of terrestrial organic matter. Overall, the marine phytoplankton $\delta^{13} \mathrm{C}$ ranges nowadays between $-10 \%$ and $-32 \%$ (Sarmiento and Gruber, 2006). However, Hayes et al. (1999) state that during Eocene the marine organic matter $\delta^{13} \mathrm{C}$ was between $-26 \%$ and $-28 \%$ (Fig. 2c). Whereas, plants characterised by a C3 photosynthesis pathway, that were the most abundant type of plants during Eocene, show a $\delta^{13} \mathrm{C}$ ranging between $-23 \%$ and $-33 \%$ (mean value $\sim-26 \%$, Maslin and Thomas, 2003).

\subsection{The Central Mediterranean carbon isotopes shifts at the Eocene- Oligocene transition}

\subsubsection{Comparison of the Mediterranean C-isotope signal with the global trend}

The upper Eocene-lower Oligocene $\delta^{13} \mathrm{C}_{\text {Carb }}$ record of the Santo Spirito ramp and the coeval $\delta^{13} \mathrm{C}_{\mathrm{TOC}}$ record of the Massignano hemipelagic succession matches the global signal (cf. Cramer et al., 2009, Fig. 5). The $\delta^{13} \mathrm{C}_{\text {Carb }}$ curves of Lettomanoppello and Massignano sections show a clear negative trend during the late Priabonian (Fig. 5a, c). This trend reflects the interval between the end of the C-cycle perturbation associated with the MECO and the onset of the carbon isotope anomaly contemporary to the Oi- 1 event, as marked by a cooling trend associated with a decrease of primary production. This decrease is well recorded by the Eocene $\delta^{13} \mathrm{C}_{\mathrm{TOC}}$ of the Massignano section, which shows an overall positive trend. Variations in the $\delta^{13} \mathrm{C}_{\mathrm{TOC}}$ might be due to the exogenic carbon pool or related to changes in the source of the organic matter (terrestrial vs marine) (Sluijs and Dickens, 2012). Further studies would be needed to entirely exclude biases related to the different sources of organic matter, such as the analysis of the 

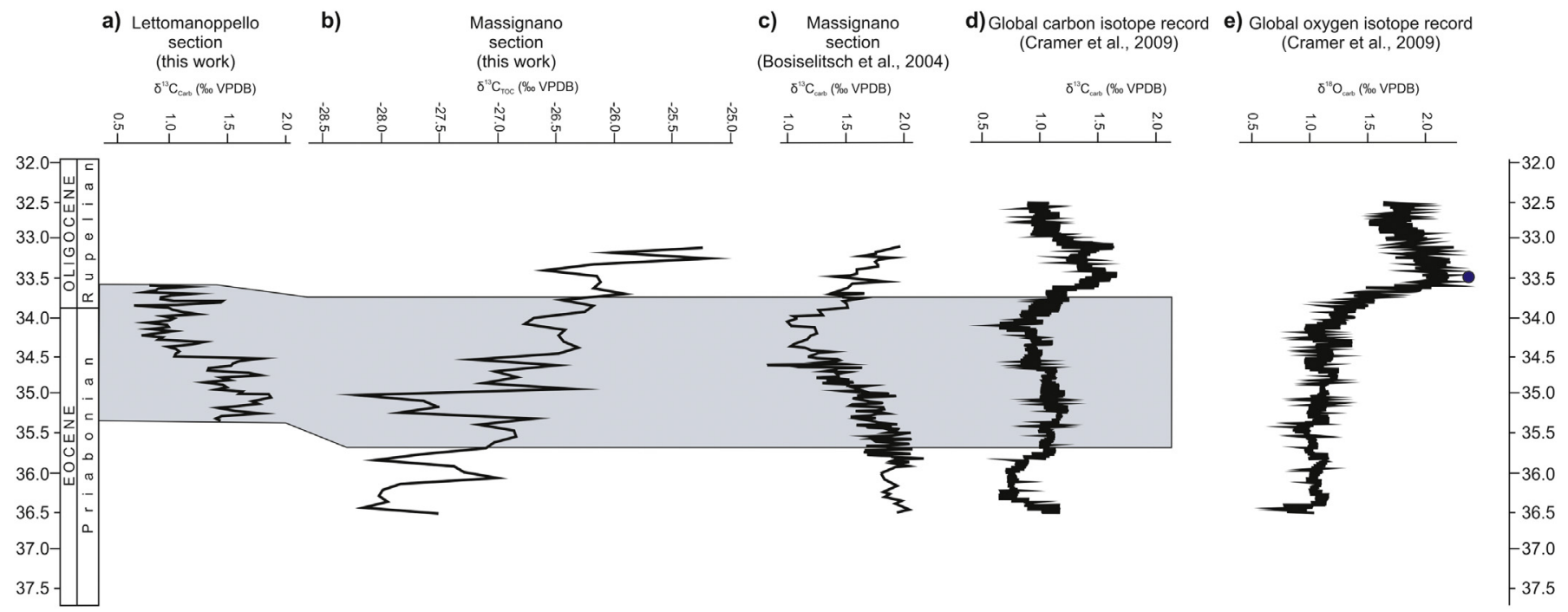

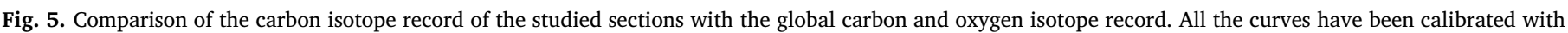
the Geological Time Scale 2004.

palynofacies, or the integration of the N/C ratio across the investigated section, to quantify precisely the variation of the amount of the terrestrial organic matter. These studies, besides useful, go beyond the scope of this work. Furthermore, the site and the paleodepth of the Massignano section already guarantee that the potential biases related to the influence of the terrestrial organic matter, even if possible, must have been minor or unlikely. In fact, the paleodepth of the Massignano section is estimated between 1000 and $1500 \mathrm{~m}$ (Coccioni and Galeotti, 2003). At this depth the marine phytoplankton derived organic matter is always significantly more abundant than the terrestrial organic matter (Berner, 1989). Secondly, during late Eocene, the Apennine orogeny front was located far more west than today, and the absence of coarse-grained sediments within the Massignano succession provides an evidence that the continent was not close. Lastly, in oxic deposits the terrestrial organic matter is strongly degraded due to heterotrophs feeding and bioturbation, and usually appears as sparse amorphous particles and pellets (Lallier-Vergès and Albéric, 1990). For these reasons, even if we cannot rule out completely the influence of the terrestrial organic matter on the $\delta^{13} \mathrm{C}_{\mathrm{TOC}}$ record at Massignano, we can definitely assume that it would have been unlikely and scarce.

The c-cycle perturbation that occurred during the Oi-1 has long been debated. The different interpretations vary from feedbacks among atmospheric $\mathrm{pCO}_{2}$ and ice sheet coverage and silicate weathering rates, to increased marine organic carbon burial/cycling. Different hypotheses suggest a global switch in the ecology of plankton that favoured siliceous organisms over calcareous ones, a shift in global carbonate sedimentation from the shelf to the deep ocean, changes in riverine chemical inputs, a heavier isotopic composition of the terrestrial biosphere, or an increase in the rain ratio of the inorganic/organic carbon from surface to deep ocean, to a reduced ocean acidity linked to an increased ocean overturning (Coxall and Wilson, 2011; Plancq et al., 2014).

According to Goldner et al. (2014), the decrease of atmospheric $\mathrm{pCO}_{2}$ during the EOT produced the cooling phase that promoted the growth of the Antarctica ice cap, which in turn enhanced the ocean thermal gradient and invigorated its circulation. The increased winddriven upwelling around Antarctica drove an increase in ocean productivity, potentially drawing down carbon. Furthermore, it strengthened the cooling across the EOT, pointing towards a C-cycle perturbation related to the enhanced burial rates of organic carbon in marine sediments, coupled with increased surface water productivity (Salamy and Zachos, 1999; Zachos and Kump, 2005; Dunkley Jones et al., 2008).

\subsubsection{Decoupling between ${ }^{13} C_{\text {Carb }}$ and ${ }^{13} C_{\text {TOC }}$}

The upper Eocene $\delta^{13} \mathrm{C}_{\mathrm{Carb}}$ and the $\delta^{13} \mathrm{C}_{\mathrm{TOC}}$ curves of the analysed successions show opposite trends. This decoupling during the late Priabonian is consistent with the decreasing values of $\mathrm{CO}_{2}$ that characterise the late Eocene (Beerling and Royer, 2011; Foster et al., 2017) (Fig. 5a, b). The net isotopic fractionation between the total organic carbon (TOC) and sedimentary carbonates depends on four processes: the fractionation associated with primary producers, the fractionation between Dissolved Inorganic Carbon (DIC) and dissolved $\mathrm{CO}_{2}$, the fractionation between DIC and carbonate minerals, and the fractionation associated with secondary biological processes (see Hayes et al., 1999 for a review). Among these processes, the first one is the most effective, but it has not been constant throughout time. In fact, Hayes et al. (1999) point out how the isotopic effect associated with primary production decreases as dissolved $\mathrm{CO}_{2}$ lowers, affecting the TOC sequestrated in sediments, thus increasing the difference between the TOC and the DIC.

Within the overall positive $\delta^{13} \mathrm{C}_{\mathrm{TOC}}$ trend, negative spikes are present in the interval between 36.5 and 36.0 Ma of the Massignano record (Figs. 2 and $6 \mathrm{a}$ ). These spikes may be related to the environmental changes produced by the alternating activity of the westward subtropical Eocene Neo-tethys (STENT) current, as proposed by Jovane et al., 2007; Jovane et al., 2009. According to the authors, the paleoceanography of the Neo-tethys was characterised by alternating periods of low productivity, represented by intervals of deposition driven by local terrigenous material, and expressed by the authors as coarser magnetite and periods of high productivity and freshening, displayed by abundant fine-grained magnetite plus hematite layers.

The high productivity and freshening periods represent times when the westward subtropical Eocene Neo-tethys current entered through the Arabia-Eurasian gateway, bringing large amounts of fresh and deepsea waters rich in dissolved iron. The negative spikes of $\delta^{13} \mathrm{C}_{\mathrm{TOC}}$ of the Massignano section show a good correspondence with the fine hematite-rich sediments interval recognised by Jovane et al., 2007, and confirm the coexistence of the high biogenic productivity phases (Fig. 6). Lastly, in the Massignano section, the onset of the positive carbon isotope excursion of the early Oligocene is recorded (Bodiselitsch et al., 2004), although in the section the entire perturbation is not displayed (Fig. 5c).

\subsubsection{C-isotope trend and sea-level changes}

The Priabonian $\delta^{13} \mathrm{C}_{\text {Carb }}$ curve of the Santo Spirito ramp at Lettomanoppello section shows the end of upper Eocene carbon isotope 


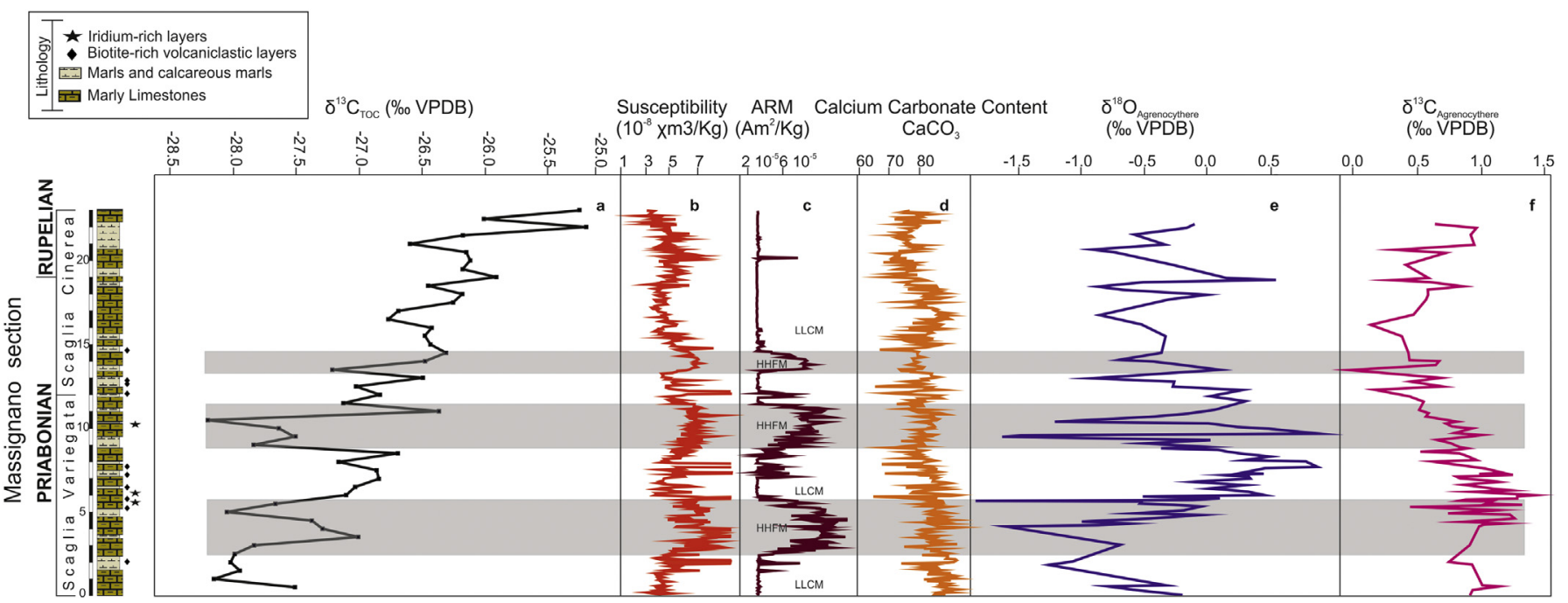

Fig. 6. a) Comparison of the $\delta^{13} \mathrm{C}_{\mathrm{TOC}}$ record of the Massignano (this work). b) Low-field magnetic susceptibility of the Massignano section. c) Anhysteretic Remanent Magnetization (ARM). d) Calcium Carbonate Content (CaCO3\%), e) $\delta^{18} \mathrm{O}$, and f) $\delta^{13} \mathrm{C}$ isotope record measured on valves of the Agrenocythere ostracod genera throughout the Massignano section. (b), (c), (d), and (f) are modified from Jovane et al. (2009). HHFM = high concentration, high coercivity, and fine-grained magnetic; LLCM = low concentration, low coercivity, and coarse-grained magnetic (modified from Jovane et al., 2004).

negative trend, which is linked to the decrease of primary production at the end of the Eocene (Fig. 5a). The prominent $\delta^{13} \mathrm{C}$ excursion occurring in the early Oligocene associated with the onset of Antarctic glaciation is not recorded because the regular bedding is interrupted by the occurrence of extensive slumps. These slumps are indeed interpreted as the major consequence of the sea-level drop related to the cooling corresponding to the Oi-1 event. Slumps in the lower Oligocene (within Zone CNO1 of Agnini et al., 2014) have been identified not only in the Lettomanoppello and in the Orfento Valley sections (Figs. 2a, b, and $3 \mathrm{~b}$ ), but also in the eastern sector of the Santo Spirito ramp, namely in the Pennapiedimonte stratigraphic section (Raffi et al., 2016), and indicate an enhanced instability over the entire ramp.

Houben et al. (2012), in a study of the Eocene-Oligocene succession of the Berici Mountain (Northern Italy), estimated a $\sim 20 \mathrm{~m}$ sea level drop in correspondence with the Eocene-Oligocene boundary related to the EOT, and then a further $\sim 60 \mathrm{~m}$ drop related to the Oi-1 event and the glaciation of Antarctica. Similarly, Miller et al. (2009) suggested a sea level drop related to the Oi-1 event of $80 \pm 25 \mathrm{~m}$. In this framework, the occurrence of extensive slumps indicates the deepening of the storm weather wave base. It is widely accepted that slumps and softsediment deformation structures can be triggered by storm waves (Molina et al., 1998). The intensification and the more frequent occurrence of storm events on the Santo Spirito ramp could have also been enhanced by the onset of the new oceanographic conditions and strong wind-driven currents related to the stronger latitudinal gradient (Coxall and Pearson, 2007; Miller et al., 2009).

\subsubsection{Productivity conditions and carbonate factory response}

The high biogenic productivity phases recorded during the late Eocene in the pelagic realm, testified by the negative $\delta^{13} \mathrm{C}_{\mathrm{TOC}}$ spikes at Massignano section, do not seem to be equally recorded in the platform domain. Apparently, no significant changes in the carbonate factory of the Santo Spirito ramp occurred concomitantly with the EOT. On the other hand, since the depositional environment of Santo Spirito Formation identifies an outer ramp setting, the carbonate factory was consequently dominated by aphotic biota, such as small benthic foraminifera, mollusc and echinoid fragments, coupled with the pelagic components represented by the planktonic foraminifera accumulating in the outer ramp. Relevant compositional changes are observed only in the resedimented interval (floatstone to rudstone lithofacies) marked by the disappearance of Discoyclina specimens, the reduced occurrence of
Nummulites, and the spreading of red algae and corals.

A drastic change of the carbonate factory is recorded in the western margin of the Lessini shelf (Jaramillo-Vogel et al., 2013, 2016). While red algae and LBF dominate in the lower portion of the succession, its uppermost part is characterised by bryozoan-rich beds. According to Jaramillo-Vogel et al. (2013, 2016), the disappearance of Discocyclina and Asterocyclina, and the replacement of phototrophic organisms by heterotrophic ones could be due to a significant change in the environmental conditions. This change corresponds to a sharp positive shift in $\delta^{13} \mathrm{C}$ that starts just below the bryozoan beds and is interpreted as the main C-cycle perturbation occurring at the EOT.

This perturbation is associated with a major change in trophic resources as indicated in the Lessini Shelf by a rise in the total phosphorus content, which triggered an increased primary productivity and thus, a shallowing of the photic zone (Jaramillo-Vogel et al., 2016). Decreased water transparency would have limited light-dependent biota and left bryozoans as dominant benthic calcifying organisms.

The coeval deposition of bryozoan beds reported from other several localities in northern Italy is interpreted to represent the regional response of a carbonate platform depositional system to global oceanographic changes related to the beginning of the Antarctic glaciation. In the Southern Tethys platforms (Hyblea, southern Apula, Malta), the progressive global cooling at the EOT produced a major decline of larger benthic foraminiferal assemblages. The Discocyclina genus disappeared as well as most of the Nummulites species, whereas coral bioconstructions underwent renewed development. Lastly, coralline algae became a dominant sediment-producing biota, and seagrass environments expanded, causing a change in the facies association of the Cenozoic carbonate platforms (Pedley, 1998; Nebelsick et al., 2005; Brandano et al., 2009, 2017a).

\section{Conclusions}

The data here presented testify that the oceanic carbon isotope trends have been recorded in the Neo-thetys shallow-water (Santo Spirito Formation, Majella Mountain, northern Apula Platform) and basinal successions (Massignano section) since they overall match the deep-sea signal. The shallow-water $\delta^{13} \mathrm{C}_{\mathrm{Carb}}$ record of the upper Eocene shows an overall negative trend, while the contemporary $\delta^{13} \mathrm{C}_{\mathrm{TOC}}$ records a positive one. This general trend is related to reduced fractionation by primary producers during the late Eocene due to the 
decreasing $\mathrm{pCO}_{2}$ after the C-cycle perturbation of the MECO, and before the onset of the carbon anomaly linked to the Oi-1 event. However, this study proves that regional factors, superimposed to the global forcing, influenced the Neo-thetys carbon isotope record, as suggested by the sharp transient negative spikes that mark the $\delta^{13} \mathrm{C}_{\mathrm{TOC}}$ record of the Massignano section. The Neothetys paleoceanography and current patterns mostly controlled these short-term anomalies. They are indeed interpreted as short times of higher productivity linked to enhanced nutrient availability and triggered by the westward subtropical Eocene Neo-tethys current entering from the Arabian-Eurasian gateway.

In contrast, the shallow-water carbon isotope signal does not record these short-term pulses of productivity. In fact, no significant changes in the carbonate factory of the Santo Spirito Formation are recorded. This fact does not mean a minor sensitivity of shallow-water successions, but it is related to the investigated depositional environments that range from the outer ramp to a pelagic setting where only photo-independent organisms occur and accumulate. However, the compositional characteristics of the resedimented sediments from the photic zone of the ramp throughout the EOT indicate a change in the composition of the carbonate factory during the Oligocene, with the disappearance of orthophragminids, the reduction of Nummulites, and the expansion of biota associated with the seagrass together with the spread of corals and red algae. Furthermore, the Santo Spirito Formation does not record the major carbon isotope shift concomitantly with the Oi-1 event as in the lowermost Oligocene the regular bedding of the sedimentary succession is interrupted by the occurrence of extensive slumps. The slumps represent evidence of the sea-level drop that occurred at the onset of the Antarctica ice-sheet, which caused the deepening of the storm wave base, and eventually increased instability over the whole ramp. This discovery is even more important if the rarity of continuous shallowwater successions across the Eocene-Oligocene transition, due to the major sea level drop, is taken into consideration.

Finally, this study proves how different evidences may characterise the shallow-water systems response to Eocene-Oligocene transition in comparison to the pelagic settings, attesting the importance of integrated studies to understand the complex dynamics related to the greenhouse-icehouse climate transition.

\section{Acknowledgements}

This research benefitted from the financial support of the Sapienza, Università di Roma (Ateneo Project, MB; Avvio alla Ricerca Project, IC), from the Università degli Studi "G. d'Annunzio" di Chieti-Pescara (IR), and from the IAS Post-graduate Grant Scheme 2015 (IC). Comments and criticisms from Editor Liviu Matenco, E. Mattioli and an anonymous reviewer significantly improved this manuscript. Many thanks go to Dr. Domenico Mannetta for providing the thin sections, and to Dr. Mauro Brilli and Dr. Francesca Giustini for their help in the isotope geochemistry laboratory.

\section{References}

Agnini, C., Fornaciari, E., Raffi, I., Catanzariti, R., Pälike, H., Backman, J., Rio, D., 2014. Biozonation and biochronology of Paleogene calcareous nannofossils from low and middle latitudes. Newsl. Stratigr. 47, 131-181.

Alvarez, W., 1990. Pattern of extensional faulting in pelagic carbonates of the UmbriaMarche Apennines of central Italy. Geology 18, 407-410.

Alvarez, W., 1999. Drainage on evolving fold-thrust belts: a study of transverse canyons in the Apennines. Basin Res. 11, 267-284.

Alvarez, W., Cocozza, T., Wezel, F.C., 1974. Fragmentation of the Alpine orogenic belt by microplate dispersal. Nature 248, 309.

Bally, A.W., Burbi, L., Cooper, C., Ghelardoni, R., 1986. Balanced sections and seismic reflection profiles across the Central Apennines. Mem. Soc. Geol. It, 35, 257 310.Bassi, D., 2005. Larger foraminiferal and coralline algal facies in an Upper Eocene storm-influenced, shallow-water carbonate platform (Colli Berici, northeastern Italy). Palaeogeogr. Palaeoclimatol. Palaeoecol. 226, 17-35.

Bassi, D., 2005. Larger foraminiferal and coralline algal facies in an Upper Eocene storminfluenced, shallow-water carbonate platform (Colli Berici, north-eastern Italy). Palaeogeogr. Palaeoclimatol. Palaeoecol. 226, 17-35.

Beavington-Penney, S.J., Wright, V.P., Woelkerling, W.J., 2004. Recognising macrophyte- vegetated environments in the rock record: a new criterion using 'hooked' forms of crustose coralline red algae. Sediment. Geol. 166, 1-9.

Beavington-Penney, S.J., Wright, V.P., Racey, A., 2005. Sediment production and dispersal on foraminifera-dominated early tertiary ramps: the Eocene El Garia formation, Tunisia. Sedimentology 52, 537-569.

Beerling, D.J., Royer, D.L., 2011. Convergent cenozoic $\mathrm{CO}_{2}$ history. Nat. Geosci. 4, 418

Berggren, W.A., Kent, D.V., Swisher III, C.C., Aubry, M.-P., Swisher III, C.C., 1995. A revised Cenozoic geochronology and chronostratigraphy. In: Berggren, W.A., Kent, D.V., Aubry, M.-P., Hardenbol, J. (Eds.), Geochronology, Time Scales, and Global Stratigraphic Correlation. Vol. 54. SEPM (Society for Sedimentary Geology) Special Publication, pp. 129-212.

Berner, R.A., 1989. Biogeochemical cycles of carbon and sulfur and their effect on atmospheric oxygen over Phanerozoic time. Glob. Planet. Chang. 1, 97-122.

Bernoulli, D., 2001. Mesozoic-Tertiary carbonate platforms, slopes and basins of the External Apennines and Sicily. In: Vai, G.B., Martini, I.P. (Eds.), Anatomy of an Orogen: The Apennines and Adjacent Mediterranean Basins. Kluwer Academic Publishers, pp. 307-326.

Bernoulli, D., Jenkyns, H., 1974. Alpine, Mediterranean, and central Atlantic Mesozoic facies in relation to the early evolution of the Tethys. In: Modern and Ancient Geosynclinal Sedimentation (Dott, R.H., Shaves, R.H. Eds.). vol. 19. SEPM Spec. Publ., pp. 129-157.

Blow, W.H., 1969. Late middle Eocene to Recent planktonic foraminiferal biostratigraphy. In: Bronnimann, P., Renz, H.H. (Eds.), Proceedings of the First International Conference on Planktonic Microfossils (Geneva, 1967). E.J. Brill, Leiden, pp. $199-421$.

Boccaletti, M., Ciaranfi, N., Cosentino, D., Deiana, G., Gelati, R., Lentini, F., Massari, F., Moratti, G., Pescatore, T., Ricci Lucchi, F., Tortorici, L., 1990. Palinspastic restoration and paleogeographic reconstruction of the peri-Tyrrenian area during the Neogene. Palaeogeogr. Palaeoclimatol. Palaeoecol. 77, 41-50.

Bodiselitsch, B., Montanari, A., Koeberl, C., Coccioni, R., 2004. Delayed climate cooling in the late Eocene caused by multiple impacts: high-resolution geochemical studies at Massignano, Italy. Earth Planet. Sci. Lett. 223, 283-302.

Bohaty, S.M., Zachos, J.C., Delaney, M.L., 2012. Foraminiferal Mg/Ca evidence for Southern Ocean cooling across the eocene-oligocene transition. Earth Planet. Sci. Lett. 317, 251-261.

Bown, P.R., Young, J.R., 1998. Techniques. In: Brown, P.R. (Ed.), Calcareous nannofossil biostratigraphy. Micropaleontological Society Publication Series Chapman \& Hall, pp. $16-28$

Bramlette, M.N., Riedel, W.R., 1954. Stratigraphic value of discoasters and some other microfossils related to recent coccolithophores. J. Paleontol. 385-403.

Brandano, M., Frezza, V., Tomassetti, L., Cuffaro, M., 2009. Heterozoan carbonates in oligotrophic tropical waters: the Attard member of the lower coralline limestone formation (Upper Oligocene, Malta). Palaeogeogr. Palaeoclimatol. Palaeoecol. 274, 54-63.

Brandano, M., Lipparini, L., Campagnoni, V., Tomassetti, L., 2012. Downslope-migrating large dunes in the Chattian carbonate ramp of the Majella Mountains (Central Apennines, Italy). Sed. Geol. 255, 29-41.

Brandano, M., Lustrino, M., Cornacchia, I., Sprovieri, M., 2015. Global and regional factors responsible for the drowning of the Central Apennine Chattian carbonate platforms. Geol. J. 50, 575-591.

Brandano, M., Cornacchia, I., Raffi, I., Tomassetti, L., 2016a. The Oligocene-Miocene stratigraphic evolution of the Majella carbonate platform (Central Apennines, Italy). Sed. Geol. 333, 1-14.

Brandano, M., Corda, L., Tomassetti, L., Tagliavento, M., 2016b. Frequency analysis across the drowning of a lower Jurassic Carbonate Platform: the Calcare Massiccio formation (Apennines, Italy). Mar. Petrol. Geol. 78, 606-620.

Brandano, M., Cuffaro, M., Gaglianone, G., Petricca, P., Stagno, V., Mateu-Vicens, G., 2016c. Evaluating the role of seagrass in Cenozoic $\mathrm{CO}_{2}$ variations. Frontiers in Environmental Science 4 (72), 1-9.

Brandano, M., Cornacchia, I., Tomassetti, L., 2017a. Global Versus Regional Influence on the Carbonate Factories of Oligo-Miocene Carbonate Platforms in the Mediterranean Area. Marine and Petroleum Geologyhttp://dx.doi.org/10.1016/j.marpetgeo.2017. 03.001 .

Brandano, M., Cornacchia, I., Raffi, I., Tomassetti, L., Agostini, S., 2017b. The Monterey event within the Central Mediterranean area: the shallow-water record. Sedimentology 64, 286-310.

Bukry, D., 1973. Low-latitude coccolith biostratigraphic zonation. In: Edgar, N.T., Saunders, J.B. (Eds.), Initial Reports DSDP 15. U. S. Govt. Printing Office, Washington, pp. 685-703. http://dx.doi.org/10.2973/dsdp.proc.15.116.1973.

Bukry, D., Bramlette, M.N., 1969. Some new and stratigraphically useful calcareous nannofossils of the Cenozoic. Tulane Studies in Geology and Paleontology 7, $131-142$.

Bukry, D., Percival Jr., S.F., 1971. New tertiary calcareous nannofossils. Tulane Studies in Geology and Paleontology 8, 123-146.

Burla, S., Heimhofer, U., Hochuli, P.A., Weissert, H., Skelton, P., 2008. Changes in sedimentary patterns of coastal and deep-sea successions from the North Atlantic (Portugal) linked to Early Cretaceous environmental change. Palaeogeogr. Palaeoclimatol. Palaeoecol. 257, 38-57.

Buxton, M.W.N., Pedley, H.M., 1989. Short paper: a standardized model for tethyan tertiary carbonate ramps. J. Geol. Soc. 146, 746-748.

Carminati, E., Lustrino, M., Cuffaro, M., Doglioni, C., 2010. Tectonics, magmatism and geodynamics of Italy: what we know and what we imagine. J. Virtual Explor. 36.

Carminati, E., Lustrino, M., Doglioni, C., 2012. Geodynamic evolution of the central and western Mediterranean Tectonics vs. igneous petrology constraints. Tectonophysics 579, 173-192.

Carnevale, G., Patacca, E., Scandone, P., 2011. Field guide to the post-conference 
excursions (Scontrone, Palena and Montagna della Majella). In: R.C.M.N.S. Interim colloquium, Scontrone (L'Aquila) 4-5 March 2011, Italy.

Carter, A., Riley, T.R., Hillenbrand, C.D., Rittner, M., 2017. Widespread Antarctic glaciation during the Late Eocene. Earth Planet. Sci. Lett. 458, 49-57.

Centamore, E., Chiocchini, G., Deiana, A., Micarelli, U., Pieruccini, M., 1971. Contributo alla conoscenza del Giurassico dell'Appennino umbro-marchigiano. Studi Geol. Camerti. 1, 7-89.

Coccioni, R., Galeotti, S., 2003. Deep-water benthic foraminiferal events from the Massignano Eocene/Oligocene boundary stratotype section and point (central Italy): Biostratigraphic, paleoecologic, and paleoceanographic implications. In: Prothero, D.R., Ivant, L.C., Nesbitt, E. (Eds.), From Greenhouse to Icehouse: The Marine EoceneOligocene Transition. Columbia University Press, New York, pp. 438-452.

Coccioni, R., Monaco, P., Monechi, S., Nocchi, M., Parisi, G., 1988. Biostratigraphy of the Eocene/Oligocene boundary at Massignano (Ancona, Italy). In: Premoli Silva, I., Coccioni, R., Montanari, A. (Eds.), The Eocene/Oligocene Boundary in the MarcheUmbria Basin (Italy): International Subcommission on Paleogene Stratigraphy Special Publication. Industrie Grafi che Fratelli Aniballi, Ancona, pp. 59-80.

Coccioni, R., Moretti, E., Nesci, O., Savelli, D., Tramontana, M., Veneri, F., Astracedi, M., 1997. Carta Geologica con Itinerari Escursionistici-Parco Naturale del Conero: Firenze. Società Elaborazioni Cartografiche.

Colacicchi, R., 1967. Geologia della Marsica orientale: Geologica Romana. vol. 6. pp. 189-316.

Cook, J., Nuccitelli, D., Green, S.A., Richardson, M., Winkler, B., Painting, R., Way, R., Jacobs, P., Skuce, A., 2013. Quantifying the consensus on anthropogenic global warming in the scientific literature. Environ. Res. lett. 8024024.

Cosentino, D., Cipollari, P., Marsili, P., Scrocca, D., 2010. Geology of the central Apennines: a regional review. In: Beltrando, M., Peccerillo, A., Mattei, M., Conticelli, S., Doglioni, C. (Eds.), The Geology of Italy. 36 Journal of the Virtual Explorer, Electronic Edition. paper 11. ISSN 1441-8142.

Coxall, H.K., Pearson, P.N., 2007. the eocene-oligocene transition. In: Deep Time Perspectives on Climate Change: Marrying the Signal from Computer Models and Biological Proxies, pp. 351-387.

Coxall, H.K., Wilson, P.A., 2011. Early Oligocene glaciation and productivity in the eastern equatorial Pacific: Insights into global carbon cycling. Paleoceanography 26 PA2221. https://doi.org/10.1029/2010PA002021.

Coxall, H.K., Wilson, P.A., Palike, H., Lear, C.H., Backman, J., 2005. Rapid stepwise onset of Antarctic glaciation and deeper calcite compensation in the Pacific Ocean. Nature 433, 53.

Cramer, B.S., Toggweiler, J.R., Wright, J.D., Katz, M.E., Miller, K.G., 2009. Ocean overturning since the Late Cretaceous: Inferences from a new benthic foraminiferal isotope compilation. Paleoceanography 24 PA4216. https://doi.org/10.1029/ 2008PA001683.

Crescenti, U., Crostella, A., Donzelli, G., Raffi, G., 1969. Stratigrafia della serie calcarea dal Lias al Miocene nella regione marchigiano-abruzzese: Parte II. Litostratigrafia, biostratigrafia, paleogeografia. Mem. Soc. Geol. It. 9, 343-420.

DeConto, R.M., Pollard, D., 2003. Rapid Cenozoic glaciation of Antarctica induced by declining atmospheric CO2. Nature 421, 245-249.

Deflandre, G., 1952. Classes de Coccolithophoridés. (Coccolithophoridae. Lohmann, 1902). In: Grassé, P.P. (Ed.), Traite de Zoologie. Masson, Paris, pp. 439-470.

Deflandre, G., Fert, C., 1954. Observations sur les coccolithophoridés actuels et fossiles en microscopie ordinaire et électronique. Annales de Paléontologie 40, 115-176.

Devoti, C., Riguzzi, F., Cuffaro, M., Doglioni, C., 2008. New GPS constraints on the kinematics of the Apennines subduction. Earth Planet. Sci. Lett. 273, 163-174.

Dewey, J.F., Helman, M.L., Turco, E., Hutton, D.H.W., Knott, S.D., 1989. Kinematics of the western Mediterranean. In: Coward, M.P., Dietrich, D., Park, R.G. (Eds.), Alpine tectonics. 45. Geol. Soc. London Spec. Publ, pp. 421-443.

Doglioni, C., 1991. A proposal for the kinematic modelling of W-dipping subductions; possible applications to the Tyrrhenian-Apennines system. Terra Nova 3, 423-434.

Doglioni, C., Mongelli, F., Pialli, C., 1998. Boudinage of the Alpine Belt in the Apenninic back-arc. Mem. Soc. Geol. It. 52, 457-468.

Dunkley, Jones T., Bown, P.R., Pearson, P.N., Wade, B.S., Coxall, H.K., Lear, C.H., 2008. Major shifts in calcareous phytoplankton assemblages through the Eocene-Oligocene transition of Tanzania and their implications for low-latitude primary production. Paleoceanography 23 PA4204.

Egan, K.E., Rickaby, R.E., Hendry, K.R., Halliday, A.N., 2013. Opening the gateways for diatoms primes Earth for Antarctic glaciation. Earth and Planetary Science Letters 375, 34-43.

Flügel, E., 2004. Microfacies of carbonate rocks. Springer Berlin Heidelberg. 976 pp.

Foster, G.L., Royer, D.L., Lunt, D.J., 2017. Future climate forcing potentially without precedent in the last 420 million years. Nature Communications 8 (14), 845.

Franceschi, M., Dal Corso, J., Posenato, R., Roghi, G., Masetti, D., Jenkyns, H.C., 2014. Early Pliensbachian (Early Jurassic) C-isotope perturbation and the diffusion of the Lithiotis Fauna: Insights from the western Tethys. Palaeogeogr., Palaeoclimatol., Palaeoecol. 410, 255-263.

Frijia, G., Parente, M., Di Lucia, M., Mutti, M., 2015. Carbon and strontium isotope stratigraphy of the Upper Cretaceous (Cenomanian-Campanian) shallow-water carbonates of southern Italy: Chronostratigraphic calibration of larger foraminifera biostratigraphy. Cretaceous Research 53, 110-139.

Galeotti, S., DeConto, R., Naish, T., Stocchi, P., Florindo, F., Pagani, M., Barret, P., Bohaty, S.M., Lanci, L., Pollard, D., Sandroni, S., Talarico, F.M., Zachos, J.C., 2016. Antarctic Ice Sheet variability across the Eocene-Oligocene boundary climate transition. Science, aab0669.Galimov, E. M., 2006. Isotope organic geochemistry. Org. Geochem. 37, 1200-1262.

Galimov, E.M., 2006. Isotope organic geochemistry. Org. Geochem. 37, 1200-1262.

Gartner Jr., S., Smith, L.A., 1967. Coccoliths and related calcareous nannofossils from the Yazoo Formation (Jackson, Late Eocene) of Louisiana. University of Kansas
Paleontological Contributions 20, 1-7.

Goldner, A., Herold, N., Huber, M., 2014. Antarctic glaciation caused ocean circulation changes at the Eocene-Oligocene transition. Nature 511, 574-577.

Grossman, E.L., Ku, T.L., 1986. Oxygen and carbon isotope fractionation in biogenic Aragonite- Temperature Effects. Chemical Geology 59, 59-74.

Gueguen, E., Doglioni, C., Fernandez, M., 1998. On the post-25 Ma geodynamic evolution of the western Mediterranean. Tectonophysics 298, 259-269.

Guerrera, F., Tramontana, M., Donatelli, U., Serrano, F., 2012. Space/time tectono-sedimentary evolution of the Umbria-Romagna-Marche Miocene Basin (Northern Apennines, Italy): a foredeep model. Swiss Journal of Geosciences 105, 325-341.

Haq, B.U., 1971. Paleogene calcareous nannoflora, part IV. Paleogene nanno-plankton biostratigraphy and evolutionary rates in Cenozoic calcareous nannoplankton. Stockholm Contribution in Geology 25, 129-158.

Hay, W.W., Mohler, H.P., Wade, M.E., 1966. Calcareous nannofossils from Nal'chik (northwest Caucasus). Eclogae Geologicae Helvetiae 59, 379-399.

Hay, W.W., Mohler, H.P., Roth, P.H., Schmidt, R.R., Boudreaux, J.E., 1967. Calcareous Nannoplankton Zonation of the Cenozoic of the Gulf Coast and Caribbean-Antillean Area, and Transoceanic Correlation. Transactions of the Gulf Coast Association of the Geological Societies 17, 428-480.

Hayes, J.M., Strauss, H., Kaufman, A.J., 1999. The abundance of C-13 in marine organic matter and isotopic fractionation in the global biogeochemical cycle of carbon during the past 800 Ma. Chemical Geology 161, 103-125.

Houben, A.J., van Mourik, C.A., Montanari, A., Coccioni, R., Brinkhuis, H., 2012. The Eocene-Oligocene transition: changes in sea level, temperature or both? Palaeogeogr., Palaeoclimatol., Palaeoecol. 335, 75-83.

Jaramillo-Vogel, D., Strasser, A., Frijia, G., Spezzaferri, S., 2013. Neritic isotope and sedimentary records of the Eocene-Oligocene greenhouse-icehouse transition: The Calcare di Nago Formation (northern Italy) in a global context. Palaeogeogr., Palaeoclimatol., Palaeoecol. 369, 361-376.

Jaramillo-Vogel, D., Bover-Arnal, T., Strasser, A., 2016. Bryozoan beds in northern Italy as a shallow-water expression of environmental changes during the Oligocene isotope event 1. Sedimentary Geology 331, 148-161.

John, C.M., Mutti, M., Adatte, T., 2003. Mixed carbonate-siliciclastic record on the North African margin (Malta) — coupling of weathering processes and mid Miocene climate. Geological Society of America Bulletin 115, 217-229.

Jovane, L., Florindo, F., Dinarès-Turell, J., 2004. Environmental magnetic record of paleoclimate change from the Eocene-Oligocene stratotype section, Massignano, Italy. Geophysical Research Letters 31 L15601. https://doi.org/10.1029/2004GL020554.

Jovane, L., Sprovieri, M., Florindo, F., Acton, G., Coccioni, R., Dall'Antonia, B., DinarèsTurell, J., 2007. Eocene-Oligocene paleoceanographic changes in the stratotype section, Massignano, Italy: Clues from rock magnetism and stable isotopes. Journal of Geophysical Research 112. http://dx.doi.org/10.1029/2007JB004963.

Jovane, L., Coccioni, R., Marsili, A., Acton, G., 2009. The late Eocene greenhouse-icehouse transition: Observations from the Massignano global stratotype section and point (GSSP). Geol. Soc. Am. Spec. Pap. 452, 149-168.

Kennet, J.P., 1977. Cenozoic evolution of Antarctic glaciation, the circum-Antarctic Ocean, and their impact on global paleoceanogrpahy. Journal of Geophysical Research 82, 384-386.

Kennet, J.P., Houtz, R.E., Andrews, P.B., Edwards, A.R., 1975. Development of the circum-Antarctic current. Science 186, 144-147.

Lallier-Vergès, E., Albéric, P., 1990. Optical and geochemical study of organic matter in present oxic sediments (equatorial North Pacific Ocean NIXO area). In: Oceanologica Acta, Spec. Issue 10, pp. 281-291.

Lear, C.H., Bailey, T.R., Pearson, P.N., Coxall, H.K., Rosenthal, Y., 2008. Cooling and ice growth across the Eocene-Oligocene transition. Geology 36, 251-254.

Levin, H.L., 1965. Coccolithoporidae and related microfossils from the Yazoo Formation (Eocene) of Mississippi. Journal of Paleontology 265-272.

Liebrand, D., Bakker, A.T., Beddow, H.M., Wilson, P.A., Bohaty, S.M., Ruessink, G., Pälikee, H., Batenburgf, S.J., Hilgen, F.J., Hodell, D.A., Huck, C.E., Kroon, D., Raffi, I., Saes, M.J.M., Dijkd, A.E., Lourensd, L.J., 2017. Evolution of the early Antarctic ice ages. Proc. Natl. Acad. Sci 201615440

Liu, Z., Pagani, M., Zinniker, D., DeConto, R., Huber, M., Brinkhuis, H., Shah, S.R., Leckie, M., Pearson, A., 2009. Global cooling during the Eocene-Oligocene climate transition. Science 323, 1187-1190.

Lustrino, M., Morra, V., Fedele, L., Franciosi, L., 2009. Beginning of the Apennine subduction system in central western Mediterranean: constraints from Cenozoic "orogenic" magmatic activity of Sardinia, Italy. Tectonics 28, TC5016. http://dx.doi.org/ 10.1029/2008TC002419.

Marchegiani, L., Bertotti, G., Cello, G., Deiana, G., Mazzoli, S., Tondi, E., 1999. Preorogenic tectonics in the Umbria-Marche sector of the Afro-Adriatic continental margin. Tectonophysics 315, 123-143.

Martini, E., 1971. Standard Tertiary and Quaternary calcareous nannoplankton zonation. In: Proceedings of the Second Planktonic Conference, Roma 1970, pp. 739-785.

Martini, E., Ritzkowski, S., 1968. Was ist das "Unter-Oligocan"? Nachrichten der Akademie der Wissenschaften in Gottingen II. Mathematisch-physikalische Klasse 13, 231-251.

Maslin, M.A., Swann, G.E.A., 2005. Isotopes in marine sediments. In: Leng, M.J. (Ed.), Isotopes in Paleoenvironmental Research. Springer, Dordrecht, Netherlands, pp. 227-290.

Maslin, M.A., Thomas, E., 2003. Balancing the deglacial global carbon budget: The hydrate factor. Quaternary Science Reviews 22, 1729-1736.

Miller, K.G., Wright, J.D., Fairbanks, R.G., 1991. Unlocking the ice house: OligoceneMiocene oxygen isotopes, eustasy, and margin erosion. Journal of Geophysical Research: Solid Earth 96, 6829-6848.

Miller, K.G., Wright, J.D., Katz, M.E., Wade, B.S., Browning, J.V., Cramer, B.S., Rosenthal, Y., 2009. Climate threshold at the Eocene-Oligocene transition: Antarctic ice sheet 
influence on ocean circulation. 452. Geological Society of America Special Papers, pp. 169-178.

Molina, J.M., Alfaro, P., Moretti, M., Soria, J.M., 1998. Soft-sediment deformation structures induced by cyclic stress of storm waves in tempestites (Miocene, Guadalquivir Basin, Spain). Terrra Nova 10, 145-150.

Mutti, M., Bernoulli, D., Stille, P., 1997. Temperate carbonate platform drowning linked to Miocene oceanographic events: Maiella platform margin, Italy. Terra Nova 9, $122-125$.

Mutti, M., Droxler, A.W., Cunningham, A.D., 2005. Evolution of the Northern Nicaragua Rise during the Oligocene-Miocene: drowning by environmental factors. Sed. Geol. 175, 237-258.

Mutti, M., John, C.M., Knoerich, A.C., 2006. Chemostratigraphy in Miocene heterozoan carbonate settings: applications, limitations and perspectives. Geol. Soc. London. Spec. Publ. 255, 307-322.

Nebelsick, J.H., Rasser, M.W., Bassi, D., 2005. Facies dynamics in Eocene to Oligocene circumalpine carbonates. Facies 51, 197-217.

Pagani, M., Huber, M., Liu, Z., Bohaty, S.M., Henderiks, J., Sijp, W., Krishnan, S., DeConto, R.M., 2011. The role of carbon dioxide during the onset of Antarctic glaciation. Science 334, 1261-1264.

Pagani, M., Huber, M., Sageman, B., 2014. Greenhouse Climates. In: Treatise on Geochemistry 2nd Eidtion. Elsevier, Oxford, pp. 281-304. http://dx.doi.org/10. 1016/B978-0-08-095975-7.01314-0.

Pälike, H., Norris, R.D., Herrle, J.O., Wilson, P.A., Coxall, H.K., Lear, C.H., Shackleton, N., Tripati, A.K., Wade, B.S., 2006. The heartbeat of the Oligocene climate system. Science $314,1894-1898$.

Parotto, M., Praturlon, A., 1975. Geological summary of the Central Apennines. In Ogniben, L., Parotto, M., Praturlon, A. (Eds.), Structural Model of Italy. 90. C.N.R., La Ricerca Scientifi ca, pp. 257-311.

Patacca, E., Scandone, P., Di Luzio, E., Cavinato, G.P., Parotto, M., 2008. Structural ar chitecture of the central Apennines: Interpretation of the CROP 11 seismic profile from the Adriatic coast to the orographic divide. Tectonics 27, TC3006 $36 \mathrm{pp}$.

Payros, A., Pujalte, V., Orue-Etxebarria, X., 2007. A point-sourced calciclastic submarine fan complex (Eocene Anotz Formation, western Pyrenees): facies architecture, evolution and controlling factors. Sedimentology 54, 137-168.

Pearson, P.N., Foster, G.L., Wade, B.S., 2009. Atmospheric carbon dioxide through the Eocene-Oligocene climate transition. Nature 461, 1110.

Pedley, M., 1998. A review of sediment distributions and processes in Oligo-Miocene ramps of southern Italy and Malta (Mediterranean divide). Geological Society; London, Special Publications 149, 163-179.

Pekar, S.F., DeConto, R.M., 2006. High-resolution ice-volume estimates for the early Miocene: evidence for a dynamic ice sheet in Antarctica. Palaeogeogr. Palaeoclimatol. Palaeoecol. 231, 101-109.

Perch-Nielsen, K., 1971. Elektronenmikroskopische Untersuchungen an Coccolithen und verwandten Formen aus dem Eozän von Dänemark. Det Kongelige Danske Videnskabernes-Selskabs Skrivter. vol. 18. pp. 1-76.

Pialli, G., 1971. Facies di piana cotidale nel Calcare Massiccio dell'Appennino UmbroMarchigiano. Boll. Soc. Geol. It. 90, 481-507.

Plancq, J., Mattioli, E., Pittet, B., Simon, L., Grossi, V., 2014. Productivity and sea-surface temperature changes recorded during the late Eocene-early Oligocene at DSDP Site 511 (South Atlantic). Palaeogeogr. Palaeoclimatol. Palaeoecol. 407, 34-44.

Pomar, L., Kendall, C.G.S.C., 2008. Architecture of carbonate platforms: a response to hydrodynamics and evolving ecology. In: Controls on carbonate platform and reef development. 89. SEPM S.P., pp. 187-216 Tulsa.

Pomar, L., Baceta, J.I., Hallock, P., Mateu-Vicens, G., Basso, D., 2017. Reef building and carbonate production modes in the west-central Tethys during the Cenozoic. Marine and Petroleum Geology 83, 261-304.

Premoli Silva, I., Jenkins, D.G., 1993. Decision on the Eocene-Oligocene boundary stratotype. Episodes 16, 379-382.

Racey, A., 2001. A review of Eocene nummulite accumulations: structure, formation and reservoir potential. Journal of Petroleum Geology 24, 79-100.

Raffi, I., Ricci, C., Garzarella, A., Brandano, M., Cornacchia, I., Tomassetti, L., 2016. Calcareous nannofossils as a dating tool in shallow marine environment: an example from an upper Paleogene carbonate platform succession in the Mediterranean. Newsletters on Stratigraphy 49, 481-495.

Rosenbaum, G., Lister, G.S., Duboz, C., 2002a. Relative motions of Africa, Iberia and Europe during Alpine Orogeny. Tectonophysics 359, 117-129.

Rosenbaum, G., Lister, G.S., Duboz, C., 2002b. Reconstruction of the tectonic evolution of the western Mediterranean since the Oligocene. J. Virt. Expl. 8, 107-130.

Salamy, K.A., Zachos, J.C., 1999. Latest Eocene-Early Oligocene climate change and Southern Ocean fertility: inferences from sediment accumulation and stable isotope data. Palaeogeography, Palaeoclimatology, Palaeoecology 145, 61-77.

Saltzman, M.R., Thomas, E., 2012. Carbon isotope stratigraphy. In: Gradstein, F.M., Ogg, J.G., Schmitz, M.D., Ogg, G.M. (Eds.), The Geologic Time Scale 2012. Elsevier, Amsterdam, pp. 207-232

Sangiorgi, F., Bijl, P.K., Passchier, S., Salzmann, U., Schouten, S., McKay, R., Cody, R.D., Pross, J., Flierdt, T., Bohaty, S.M., Levy, R., Williams, T., Escutia, C., Brinkhuis, H. 2018. Southern Ocean warming and Wilkes Land ice sheet retreat during the midMiocene. Nat. Commun. 9, 317.

Sarmiento, J.L., Gruber, N., 2006. Ocean Biogeochemical Dynamics. Princeton University Press, Princeton NJ (USA, pp. 503.

Scher, H.D., Martin, E.E., 2004. Circulation in the Southern Ocean during the Paleogene inferred from neodymium isotopes. Earth and Planetary Science Letters 228 (3) $391-405$.

Sluijs, A., Dickens, G.R., 2012. Assessing offsets between the $813 \mathrm{C}$ of sedimentary components and the global exogenic carbon pool across early Paleogene carbon cycle perturbations. Global Biogeochemical Cycles 26 (4).

Tomás, S., Frijia, G., Bömelburg, E., Zamagni, J., Perrin, C., Mutti, M., 2016. Evidence for seagrass meadows and their response to paleoenvironmental changes in the early Eocene (Jafnayn Formation, Wadi Bani Khalid, N Oman). Sedimentary Geology 341, 189-202.

Tomassetti, L., Benedetti, A., Brandano, M., 2016. Middle Eocene seagrass facies from Apennine carbonate platforms (Italy). Sedimentary Geology 335, 136-149.

Vecsei, A., Sanders, D.G.K., 1999. Facies analysis and sequence stratigraphy of a Miocene warm-temperate carbonate ramp, Montagna della Maiella, Italy. Sed. Geol. 123, 103-127.

Vecsei, A., Sanders, D.G., Bernoulli, D., Eberli, G.P., Pignatti, J.S., 1998. Cretaceous to Miocene sequence stratigraphy and evolution of the Maiella carbonate platform margin, Italy. In: Hardenbol, J., Thierry, J., Farley, M.B., Jacquin, T., De Graciansky, P.C., Vail, P.R. (Eds.), Mesozoic and Cenozoic Sequence Stratigraphy of European Basins. SEPM Special Publication, vol. 60. pp. 53-74.

Vezzani, L., Festa, A., Ghisetti, F.C., 2010. Geology and tectonic evolution of the CentralSouthern Apennines, Italy. Geol. Soc. Am. Spec. Pap. 469, 1-58.

Weissert, H., Joachimski, M., Sarnthein, M., 2008. Chemostratigraphy. Newsl. Stratigr 42, 145-179.

Wright, N.M., Scher, H.D., Seton, M., Huck, C.E., Duggan, B.D., 2018. No Change in Southern Ocean Circulation in the Indian Ocean From the Eocene Through Late Oligocene. Paleoceanography and Paleoclimatology 33 (2), 152-167.

Zachos, J.C., Kump, L.R., 2005. Carbon cycle feedbacks and the initiation of Antarctic glaciation in the earliest Oligocene. Global and Planetary Change 47, 51-66.

Zachos, J.C., Quinn, T.M., Salamy, K.A., 1996. High-resolution ( $10^{4}$ years) deep-sea foraminiferal stable isotope records of the Eocene-Oligocene climate transition. Paleoceanography 11, 251-266.

Zachos, J., Pagani, M., Sloan, L., Thomas, E., Billups, K., 2001. Trends, rhythms, and aberrations in global climate $65 \mathrm{Ma}$ to present. Science 292, 686-693. 